\title{
Riverine flood assessment in Jhang district in connection with ENSO and summer monsoon rainfall over Upper Indus Basin for 2010
}

Bushra Khalid ${ }^{1}$ 2, 3, 4 , Bueh Cholaw ${ }^{1}$, Débora Souza Alvim ${ }^{5}$, Shumaila Javeed ${ }^{6}$, Junaid Aziz $\mathrm{Khan}^{7}$, Muhammad Asif Javed ${ }^{8}$, Azmat Hayat Khan ${ }^{9}$

Corresponding author’s email: kh_bushra@yahoo.com

Corresponding author's mobile: 0092-3315719701

${ }^{1}$ International Center for Climate and Environment Sciences,

Institute of Atmospheric Physics, Chinese Academy of Sciences, Beijing 100029, China

${ }^{2}$ Earth System Physics, The Abdus Salam International Centre for Theoretical Physics, Trieste, Italy

${ }^{3}$ Department of Environmental Science, International Islamic University, Islamabad, Pakistan

${ }^{4}$ International Institute for Applied Systems Analysis, Laxenburg, Austria

${ }^{5}$ Center for Weather Forecasting and Climate Studies, National Institute for Space Research, Cachoeira Paulista, São Paulo, Brazil

${ }^{6}$ Department of Mathematics, COMSATS Institute of Information Technology, Islamabad, Pakistan

${ }^{7}$ Institute of Geographical Information System (IGIS), National University of Science and Technology (NUST), Islamabad, Pakistan

${ }^{8}$ Department of Humanities, COMSATS Institute of Information Technology, Islamabad, Pakistan

${ }^{9}$ Pakistan Meteorological Department, Quetta, Pakistan 


\section{Abstract}

Pakistan has experienced severe floods over the past decades due to climate variability. Among all the floods, the flood of 2010 was the worst in history. This study focuses on the assessment of 1) riverine flooding in the district Jhang (where Jhelum and Chenab rivers join, and the district was severely flood affected) and 2) south Asiatic summer monsoon rainfall patterns and anomalies considering the case of 2010 flood in Pakistan. The land use/cover change has been analyzed by using Landsat TM $30 \mathrm{~m}$ resolution satellite imageries for supervised classification, and three instances have been compared i.e., pre flooding, flooding, and post flooding. The water flow accumulation, drainage density and pattern, and river catchment areas have been calculated by using Shutter Radar Topography Mission digital elevation model $90 \mathrm{~m}$ resolution. The standard deviation of south Asiatic summer monsoon rainfall patterns, anomalies and normal (1979-2008) have been calculated for July, August, and September by using data set of Era interim $0.75^{\circ}$ resolution. El Niño Southern Oscillation has also been considered for its role in prevailing rainfall anomalies during the year 2010 over Upper Indus Basin region. Results show the considerable changing of land cover during the three instances in the Jhang district and water content in the rivers. Abnormal rainfall patterns over Upper Indus Basin region prevailed during summer monsoon months in the year 2010 and 2011. The El Niño (2009-2010) and its rapid phase transition to La Niña (2011-2012) may be the cause of severity and disturbances in rainfall patterns during the year 2010. The Geographical Information System techniques and model based simulated climate data sets have been used in this study which can be helpful in developing a monitoring tool for flood management.

Key words: Flooding, riverine, ENSO, monsoon, rainfall, land cover 


\section{Introduction}

Pakistan has frequently faced many meteorological disasters such as droughts and floods due to climate variability. These disasters caused environmental damages, fatalities, economic losses and displacement of population (Hashim et al. 2012; Federal Flood Commission of Pakistan 2011; Khan \& Khan 2015; National Disaster Management Authority 2011). These natural hazards cannot be prevented however the likelihood of human exposure to them can be mitigated through proper planning and management strategies. El Niño Southern Oscillation (ENSO) is the climate variability that causes fluctuations in ocean temperatures over the equatorial Pacific. ENSO shows substantial impacts on global climate and weather over the years (Hirons and Klingaman 2016). It has two phases, a warm phase, i.e., El Niño; when the ocean water becomes substantially warmer than normal (Yu et al. 2017), and a cold phase called La Niña; when the ocean water becomes substantially colder than normal and is considered nearly reverse pattern to that of El Niño (Deflorio et al. 2013; Goly and Teegavarapu 2014). ENSO has afflicted Pakistan with above or below normal rainfalls in different periods during the past decades (Rashid 2004; Arif et al. 2006; Mahmood et al. 2004; Khan 2004). Weather anomaly prevails over Pakistan during ENSO and affects summer and winter rainfall (Rashid 2004; Khan 2004). The summer monsoon rainfall faces deficit over Pakistan during El Niño events and cause meteorological droughts (a condition that may occur when precipitation is insufficient to meet the needs of established human activities (Hoyt 1938)) (Rashid 2004), whereas it receives near-normal to above-normal rainfall during La Niña years (Khan 2004), that usually cause flooding. La Niña conditions often, though not always, follow the El Niño conditions (Hirons and Klingaman 2016). 
The abnormal weather conditions prevailed during summer monsoon season over Pakistan in 2010; consequently, Pakistan received higher than normal and spatially distributed rainfall which caused flooding in the Indus, Jhelum and Chenab Rivers. The Indus River, with a length of 3,180 km and an average annual discharge of $7610 \mathrm{~m}^{3} / \mathrm{s}$, is the largest river of Pakistan and its major tributaries are Jhelum and Chenab Rivers (Gaurav et al. 2011; Ahmad 1993).

The Jhelum River drains an area that lies in the west of Pir Panjal separating Jammu and Kashmir and flow southward parallel to the Indus at an average elevation of 1680 meters. About $6000 \mathrm{Km}^{2}$ of alluvial lands are drained in the Kashmir valley by Jhelum River (Babel and Wahid 2008). It receives water from several important sources such as glaciers located in the northern areas of Pakistan (IUCN 2007). Based on a 20 years record at the rim stations of Pakistan (inflow measurement facility has been established at the rim of the Indus River tributaries and thus referred to as Rim station inflows), the main contribution to the inflow comes from the rivers of Indus, Jhelum and Chenab, which accounts for more than 95\% of the total flow (Ahmad 1993; Ahmad 2000).

River Indus and its tributaries (Sutlej, Ravi, Jhelum and Chenab Rivers) irrigates the vast plains on the south of Salt range extending to the Arabian Sea, and east of Sulaiman and Kirthar mountain ranges. These tributaries meet the Indus River at Mithan Kot. On the north of the Mithan Kot, there lies the Upper Indus Basin (UIB) and on the south lies the Lower Indus Basin. The northern areas of the Indus River are very fertile despite of the fact that this is an arid region. The fertility in this region is mainly due to the soil brought by the Rivers. The UIB consists of the northern areas of Pakistan extending to the south up to Sargodha High (Iqbal 1995). UIB comprise of northern areas of Pakistan i.e., mountain ranges including Himalayas, Hindu Kush, Pamirs, and Karakoram (Ferguson 1985), provinces of Khyber Pakhtunkhwa, Punjab and 
Jammu \& Kashmir and are covered by Jhelum \& Chenab Rivers (Babel and Wahid 2008), in addition to the River Indus and its other small tributaries.

Pakistan is highly vulnerable to hydro-meteorological events and has experienced recurring cycles of riverine flooding over the past several years. The flooding in Pakistan during the summer monsoon months of JulySeptember 2010 was 7.5 on scale of intensity. The 2010 flood affected approximately one-fifth of Pakistan's total land area and displaced 20,000,000 inhabitants with 2000 fatalities in the country (Brakenridge 2012; Chorynski et al. 2012). Flooding in the Jhelum \& Chenab Rivers started in late July and sustained by the end of 2010 due to abnormally intensified summer monsoon rainfall in UIB (Syvitski and Brakenridge 2013). Several studies have investigated the effects of recent and of past riverine flooding in different parts of Asian continent (as shown in Table. 1).

The present study investigates land use/cover assessment using supervised classification mode during 2010 flooding of the Jhelum and Chenab Rivers in the district Jhang, and monsoon rainfall patterns in UIB. Jhang district lies in the Punjab province with an area of $8,809 \mathrm{Km}^{2}$ and an estimated population of 466,121 people (for 2010) (Punjab Development Statistics 2014). The two rivers i.e., Jhelum and Chenab meet in Jhang district at the point called the Trimmu Headworks (Fig. 1). The water flow in the Indus River, the past floods in the Indus River, and the overall flood situation during 2010 in Pakistan have been discussed in detail in several studies (e.g., Syvitski and Brakenridge 2013; Hashmi et al. 2012; Mustafa \& Wrathall 2011). General waterways along the Indus River, general satellite imaging comparison of flood extent for monsoon period in 2009 and 2010, and non-meteorological reasons of flooding over Pakistan have been already discussed and published (e.g., Arslan et al. 2013; Khan et al. 2014; Gaurav et al. 2011; Webster et al. 2011; Akhtar 2012; Syvitski and Brakenridge 2013; Mustafa and Wrathall 2011). Hashmi et al. (2012) 
conducted a comprehensive study on the capacity of different Pakistan's rivers and barrages to explore their role in flood mitigation. However, the land use/cover and changes during and after flooding in Jhelum \& Chenab River catchment areas have not been studied to provide useful information for policy making and implementing mitigation plans for metropolitan areas. This study provides an insight into the weather conditions of summer monsoon rainfall prevailed during 2010 over UIB in comparison to the normal rainfall, rainfall anomalies and ENSO. This study focuses on filling the afore knowledge gap and aims at developing an understanding on the use of combined techniques in Geographical Information System and reanalysis climate data as a monitoring tool in flood management in future.

\section{Materials and Methods}

Shuttle Radar Topography Mission (SRTM) Digital Elevation Model (DEM) 90 meters resolution has been used for the calculation of water flow direction, flow accumulation, drainage density and pattern, catchment areas, and stream feature in Jhang district. Landsat TM imageries consisting seven spectral bands have been downloaded from USGS website. 6 bands (i.e., bands 1 to 5 and 7) have a spatial resolution of 30 meters whereas band 6 (thermal infrared) has a 120 meters resolution and is re-sampled to 30 meters. The imageries of May 2009, August 2009 and July 2010 have been processed for 'pre-flooding', imageries of August 2010 and September 2010 have been processed for 'flooding', and imagery of December 2010 has been processed for the 'post flooding' instances. The simulated data of rainfall ( $\mathrm{mm} /$ day) of Era interim $\left(0.75^{\circ} \times 0.75^{\circ}\right.$ resolution) has been downloaded from European Centre for Medium-Range Weather Forecasts (ECMFW) website for the years of 1979-2011. Data was analyzed for 30 years (i.e., 1979-2008) to calculate climatology (rainfall) for the summer monsoon months i.e., July, August, and September (JAS); and average daily rainfall, anomalies, and standard deviations for JAS for the years of 2009-2011. 
Daily rainfall trend (mm/day) over UIB for 1979-2016 has been shown by using 144 Era interim $\left(0.75^{\circ} \times 0.75^{\circ}\right.$ resolution $)$ data set. The El Niño events from 19812017 have been described by using daily Nino4 index from SST OI v2 1/4 degree $(\mathrm{K})$.

147 Digital satellite images have pixel values and need to be calibrated to convert into reflectance. Calibrating imagery is a pre-processing step which removes radiometric errors caused by sensor's scanning angle and distortion in an image that produces noise in addition to the true spectral radiance. ENVI's Radiometric Calibration tool provides options to calibrate imagery to radiance, reflectance, or brightness temperatures. We calibrated all the images and changed them from digital number (DN) values to reflectance. Radiometric Calibration tool also helps in classification to understand the objects by checking their spectral profile and reflectance in various bands.

Catchment delineation refers to the process of using DEM to identify features such as streams, catchment areas, and basins etc. The first input required for catchment delineation is DEM. DEM data files contain the elevation of the terrain over a specified area, usually at a fixed grid interval over the "Bare Earth”. ArcGIS was used to delineate the smaller catchments in the study area. A high flow accumulation shows the areas of concentrated flow which are down slope or on the flat surface, and can be used to identify the channels of stream. The zero flow accumulation areas represent the topographic highs. The drainage pattern was calculated by the polyline feature that in turn identifies the stream order and stream feature. The stream feature represents the linear network. Density of the drainage is calculated by stream feature that represent the linear network. This linear network is used to calculate the line density. The line density calculates the magnitude per unit area from polyline features which lie within the radius around the pixel. The search radius of calculating the linear network and density is 100 meters. The unit is based on the linear unit of the 
projection of the output spatial reference. The similar technique has been used by Khalid and Ghaffar (2015) for calculating the drainage density and patterns, flow accumulation and stream feature in different cities of Pakistan. River catchments were calculated by using the 'Watershed' application. A watershed is an upslope area that contributes flow of water to a common outlet as concentrated drainage. A larger watershed may contain many smaller watersheds, called sub-basins or catchments. In this study, calculation of river catchments determines those areas from which the Chenab and Jhelum Rivers receive water toward the drainage basin to the extent of the Jhang district.

Supervised image classification using maximum likelihood algorithm is used for mapping several classes for pre flooding, post flooding and flooding instances in study area. Image classification is a well-used and accepted technique for quantifying land cover and land use at a location and across multi-temporal phases (Alphan et al. 2009). Five classes have been identified i.e., water, vegetation, built-up area, soil and clouds for the study area. Maximum likelihood algorithm is the statistical decision in which the pixels are assigned to the class of highest probability. This gives more accurate results as compared to other algorithms. Some images of the year 2010 (August and September) had cloud cover which cause difficulty in classification as areas under cloud cover and cloud shadow reflect differently thus difficult to identify.

The classified imageries were compared to give a clear picture of the pre flooding, post flooding and flooding time situation in Jhang district. The climatic analysis has been performed to understand the anomaly and usual trend of rainfall in the region considering 30 years as normal (i.e., 1979-2008) for JAS. Furthermore, the rainfall trends in JAS for the years of 2009-2011 were also mutually compared to see the variations during the flood season of year 2010. The standard deviation average anomaly for climatic normal (1979-2008) 
and standard deviation anomaly for JAS (2009-2011) has been calculated to observe the variations of rainfall over UIB.

\section{Results}

Flow direction determines the flow of water in any of the eight directions as shown in Fig. 2. Flow accumulation conditions and drainage density of the Jhang district are shown in Fig. 3. The streams show the areas of concentrated flow and high drainage density. Total streams in the catchments identified in the study area $\left(8809 \mathrm{Km}^{2}\right)$ are 189 as shown in Fig. 4. Three instances of preflooding, flooding and post-flooding were processed and compared to estimate the change in land use/cover in the Jhang district along Jhelum and Chenab Rivers.

The images of May 2009, August 2009 and July 2010 are classified for preflooding instance. These images were compared to observe land use/cover before flooding (Figs. 5-8). The change detection statistics shows no significant change in built up area (Table 2), hence built up is represented as ' 0 ' in flooding instance while vegetation, water and soil were changed about $39.02 \%, 30.10 \%$ and 21.28\% respectively. The image classification of August 2010 and September 2010 shows the flooded district in Figs. 9 \& 10. Vegetation cover in August and September is about 54\% and 55\% respectively. Water covered about 10\% and 5\% of area in August 2010 and September 2010 respectively. Soil cover was classified about 15\% and 17\% in August and September 2010 respectively. An additional class was identified which affected the classification i.e., cloud cover, typically found during monsoon season and has been considered as a class which is about 8\% and $7 \%$ in August 2010 and September 2010 respectively as shown in Fig. 11. In the post flooding instance, vegetation cover has identified as $29 \%$, soil $25 \%$, water $1 \%$ and built up area $44 \%$ (see 
224 Figs. 12 \& 13). The overall change in area covered by different identified 225 classes is shown in Table 3.

226

227

228

229

230

231

232

233

234

235

236

237

238

239

240

241

242

243

244

245

246

247

248

249

250

The climatic normal (1979-2008) have been analyzed for JAS in UIB (Fig. 14). The analysis shows that the rainfall in July 2009 is less than normal (Fig. 15); abnormally intense conditions (causing heavy rains) prevailed in July 2010 (Fig. 16); the rainfall pattern observed to be normal in July 2011 (Fig. 17). Normal conditions are observed for August 2009 whereas abnormal conditions prevailed during August 2010 and August 2011 (Figs. 16 \&17). Normal conditions are observed in September 2009 and September 2011 whereas abnormal conditions prevailed in September 2010 (Figs. 15-17). Figs. 18-20 illustrate the prevailing anomaly during the year 2010 which can be seen when compared to the situations of 2009 and 2011. During 2010, an intense anomaly occurred over UIB during July and August. Figs. 21-22 show the standard deviations of rainfall over UIB. Standard deviation of 2009-2011 has been compared with the standard deviation of climatology (i.e., 1979-2008) (Fig. 21) that shows intense occurrence of anomaly during July and August over UIB (Fig. 22). A surge in rainfall events has been observed in years 1979, 1981, 1993, 1997, 2003, 2004, 2006, 2010, 2011, and 2016 (Fig. 23). The high values in years 1979, 2003, 2004 and 2006 is between two El Niño events whereas high values in 1981, 1993, 1997, 2010, 2011, and 2016 is between the events of El Niño and La Niña (c.f. Fig. 24). The higher values show El Niño events and the lower values show La Niña events (Fig. 24).

\section{Discussion}

SRTM DEM was acquired and preprocessed to determine flow direction, flow accumulation, drainage density and to delineate the catchments of study area and is shown in Figs. (2-4). The water flow is south and south-eastward, catchments meet up in the south and drainage density becomes higher at this 
point where Rivers of Jhelum and Chenab meets. The catchments with highest water flow are dark blue whereas areas with the lowest flow are red. The high flows are apparent in the areas where both the rivers of Jhelum and Chenab merge. The catchments drain all the water to a single point and form a drainage pattern (Fig. 4).

The pre-flooding, flooding, and post flooding instances have been discussed in the following section. The land preparation and sowing season starts in April and May for Kharif crops (the crops cultivated and harvested in South Asian countries in summer monsoon season which bring rains that lasts from April to October depending on the area) that is why most of the area in district Jhang has been classified as soil/open land. The Punjab province starts to receive monsoon rains by the end of June that helps in cultivation for Kharif crop. Therefore area in May 2009 has been shown as covered with vegetation by around 26.1\% of the Jhang district and has further considered in vegetation class. This is also the time when harvesting of sugarcane starts in this region. Vegetation cover has increased in pre flooding instance i.e., August 2009 and in flooding instance in July 2010 respectively as the cultivation of other crops like rice and maize etc. increases at this time. No significant change has been observed in built up area while water cover has significantly increased in August 2009 and July 2010 due to summer monsoon rainfall and riverine flooding. Flood hit the Jhang district in August 2010 and receded slowly. The classified imageries of August 2010 (Fig. 9) and September 2010 (Fig. 10) show the flooded district. The vegetation is lush during August 2010 and September 2010 and increased chlorophyll content has been recorded during these months which are identified in NIR bands. August showing the highest vegetation covers in comparison to all instances. In September 2010 vegetation cover decreases because of crops' harvesting. Here it is observed that $5 \%$ of water receded in a span of one month. Water class is increased in flooding instance to about 5 times as compared to the 
pre-flooding instance. The soil cover decreased to about half of what it was in pre-flooding instance. Most important impact of flood is observed on built up area class that enormously reduced from 44\% in August 2009 to 13\% and 14\% in August 2010 and September 2010 respectively. Analysis of satellite imageries for above mentioned period shows that most of the built up area was affected during the flood. Post-flooding instance clearly depicts the flooded water has almost completely receded and again the land preparation period for new cultivation has been started. Vegetation is only $29 \%$ in the post flooding instance as it is the harvesting and land preparation season. Built up area is again recovered and identified in December 2010 imagery after the flood water has receded. Built up area is about $44 \%$ as it was in pre-flooding instance. Water has regained its position and covers the river course only which is about $2 \%$. Soil is identified around $25 \%$ which is almost the same as it was in preflooding instance. Comparison of pre and post flooding images with flooding instance show the significant change in built up area. Built up area has increased in post-flooding month probably due to receded water and rehabilitation activities. Water content was highest in August 2010 due to flooding while it slowly receded back in post flooding instance. Vegetation content is at its peak in August and September of both years (2009 \& 2010); chlorophyll content is found largely in crops in these months and is identified in near Infrared bands. In May 2009 and December 2010, vegetation is less and bare soil has shown an increasing trend.

The floods of 2010 negatively affected the socio-economic activities and human settlements all over Pakistan and in the Jhang district. The flooding caused due to higher than normal summer monsoon rainfall in the UIB. The water flows south and south eastward towards the human settlements and passes through the provinces of Khyber Pakhtun Khawa (KPK), Punjab, and Sind before it meets Arabian Sea in the south. Severe rainfall with abnormal trends during 2011 
compared to previous years was also observed in the study area. According to the National Disaster Management Authority (2011), approximately 6,006,545 people from 23 districts were affected and 14,187 people were injured due to floods all over the country.

It is clear from climatic analysis Figs. 14-20 the intense rainfall pattern has been shown in UIB during JAS 2010 and August 2011. The summer monsoon rainfall had deviated pattern and intense anomalies prevailed in 2010. The standard deviation charts also showing the change in rainfall patterns in 20092011 as compared to the climatology standard deviation (Fig 21-22). The interdecadal climate variability has contributed to the exacerbation and severity of floods in 2010 and 2011. ENSO Southern oscillation may have contributed to the variability in summer monsoon rainfall during 2010. Pakistan receives less than normal rainfall during El Niño years and the reverse effects have been observed during La Niña years or between two El Niño events, and between consecutive El Niño or La Niña events as shown by Figs 23-24. These figures show abnormally intensified rainfall events as the El Niño dissipates or some times between two El Niño events or between two consecutive El Niño and La Niña events. The higher than normal rainfall in monsoon season of year 2010 may also be a similar effect of dissipating the El Niño of 2009-2010 or between two consecutive events of El Niño (i.e., 2009-2010) and La Niña (i.e., 20112012) following the pattern from the past. The warm pool El Niño of 2009-2010 is unique as it followed the strongest warming signal in the central Pacific but rapidly decayed to strong La Niña of 2011-2012 (Kim et al. 2011). This El Niño was not only the warm pool event with highest central Pacific sea surface temperature anomaly but also the fastest phase transition to La Niña among other warm pool El Niño events (Lee and McPhaden 2010; Kim et al. 2011). 


\section{Conclusion}

335 This study focused on the land use/ cover changes occurred in the district Jhang in Punjab province where the two large rivers i.e., Jhelum and Chenab Rivers meets at the Trimmu Headworks. The Landsat TM satellite imageries have been processed for supervised classification and five classes are identified i.e., water, vegetation, built-up area, soil and clouds. The comparison of pre flooding, flooding and post flooding instances revealed land cover changes during the three periods in the Jhang district. Comparison of pre \& post flooding instances showed the significant decrease in built up area during flooding instances i.e., from $44 \%$ to $13 \%$. Built-up area again increased in post flooding instance as the water receded and post flooding re-habilitation activities. Water content is maximum in the rivers in August 2010. Vegetation has shown a peak in AugustSeptember 2009 and 2010 while in May 2009 and December 2010, vegetation has decreased and bare soil has increased. River catchments, flow direction, flow accumulation, drainage density and pattern have also been identified in the study area using SRTM digital elevation model. The south Asiatic monsoon pattern over UIB has also been analysed. The abnormal rainfall patterns (anomalies) have been observed during 2010 and 2011 when compared to the normal. The ENSO has been identified playing its role in disturbances generated in summer monsoon rainfall patterns during 2010-2011. The abnormally intensified El Niño during 2009-2010 and its rapid phase transition to La Niña 2011-2012 has contributed to the exacerbation and severity of rainfall over Pakistan during 2010. An interactive automated application can be made on the methodology which can serve the purpose of web-based flood delineation tool involving GIS and reanalysis model data sets. Identified sub-basins can be further used for flood risk mapping. This analysis can be used in further management and planning for natural resource and flood management. 


\section{Author's contributions}

363 BK and JAK designed research and maintained the pattern; DSA performed climatic analysis; JAK, performed the remote sensing analysis; BK interpreted the results of climatic \& remote sensing analysis and prepared the manuscript; SJ and MAJ contributed with expert guidance on technical aspects; BC supervised and gave permission to conduct the research; MAJ and AHK revised and improved the manuscript.

\section{Declaration of Competing Interests}

There are no competing interests among author and coauthors.

\section{References}

1. Arnell NW, Gosling SN (2016). The impacts of climate change on river flood risk at the global scale. Climatic Change, 134: 387.

2. Arslan M, Tauseef M, Gull M, Baqir M, Ahmad I, Ashraf U, Tawabini BS (2013). Unusual rainfall shift during monsoon period of 2010 in Pakistan: Flash flooding in Northern Pakistan and riverine flooding in Southern Pakistan. African journal of environmental science and technology, 7: 882-890.

3. Akhtar S (2012). South Asiatic monsoon and flood hazards in the Indus River basin: a study of flood hazards in Pakistan paperback - August 7, 2012. LAP LAMBERT Academic Publishing.

4. Alphan H, Doygun H, Unlukaplan YI (2009). Post-classification comparison of land cover using multitemporal Landsat and ASTER imagery: the case of Kahramanmaraş, Turkey. Environmental monitoring and assessment, 151, 327-336.

5. Ahmad N (1993).Water resources of Pakistan. Publisher Shahzad Nazir, Gulberg, Lahore, Pakistan 
6. Ahmad S, Mohammad A, Khan ST (2000) Water resources of Pakistan-A country report. Water Resources Research Institute, National Agricultural Research Centre, Islamabad

7. Brakenridge GR (2012). Global active archive of large flood events: Dartmouth Flood Observatory, University of Colorado.

8. Babel M, Wahid S (2008). Freshwater under threat: South Asia: Vulnerability Assessment of Freshwater Resources to Environmental Change. Nairobi, Kenya: United Nations Environment Programme.

9. Chohan K, Ahmad SR, Islam Z, Adrees M (2015). Riverine flood damage assessment of cultivated lands along Chenab River using GIS and remotely sensed data: A case study of district Hafizabad, Punjab, Pakistan. Journal of geographical information system, 7: 506-526.

10.Chorynski A, Pinskwar I, Kron W, Brakenridge R, Kundzewicz ZW (2012). Catalogue of large floods in Europe in the 20th century, in Kundzewicz, Z.W., ed., Changes in Flood Risk in Europe: Wallingford, UK, IAHS Press Special Publication 10: 27-54.

11. Dewan TH (2015). Societal impacts and vulnerability to floods in Bangladesh and Nepal. Weather and Climate Extremes, 7: 36-42.

12.Doocy S, Daniels A, Murray S, Kirsch TD (2013). The Human Impact of Floods: a Historical Review of Events 1980-2009 and Systematic Literature Review. PLOS Currents Disasters. doi: 0.1371/currents.dis.f4deb457904936b07c09daa98ee8171a.

13.Deflorio MJ, Pierce DW, Cayan DR, Miller AJ (2013). Western U.S. extreme precipitation events and their relation to ENSO and PDO in CCSM4, J. Clim., 26, 4231-4243.

14.FFC (2011). Federal Flood Commission of Pakistan, Annual Flood Report-2010. 
15.Ferguson RI (1985). Runoff from Glacierized Mountains: A Model for Annual Variation and Its Forecasting. Water Resources Research 21(5): 702-08.

16.Ghosh S, Mistri B (2015). Geographic Concerns on Flood Climate and Flood Hydrology in Monsoon-Dominated Damodar River Basin, Eastern India. Geography Journal, Article ID 486740. doi:10.1155/2015/486740.

17.Goly A, Teegavarapu RSV (2014). Individual and coupled influences of AMO ENSO on regional precipitation characteristics and extremes, Water Resour. Res., 50, 4686-4709, doi:10.1002/2013WR014540.

18.Gaurav K, Sinha R, Panda PK (2011). The Indus flood of 2010 in Pakistan: a perspective analysis using remote sensing data. Nat Hazards, 59: 1815-1826.

19.Hirons L, Klingaman N (2016). La Nina 2016/2017 historical impact analysis. Report by Climate, environment, infrastructure and Livelihoods Professional Evidence and Applied Knowledge Services (CEIL PEAKS) programme, Evidence on Demand organization.

20.Hashmi HN, Siddiqui QTM, Ghumman AR, Kamal MA, Mughal HR (2012). A critical analysis of 2010 floods in Pakistan. African Journal of Agricultural Research, 7:1054-1067.

21.Hoyt, JC (1938). Drought of 1936, with discussion of the significance of drought in relation to climate. U.S. Geological Survey, Water Supply Paper No. 820. p. 1.

22.Iqbal B (1995). Petroleum geology of Pakistan. Pakistan Petroleum Limited. Karachi, Pakistan.

23.IUCN (2007). Pakistan Water Gateway. Accessed online in June 2017 at $<$ http://www.waterinfo.net.pk/index.cfm>

24.Khalid B, Ghaffar A (2015). Dengue transmission based on urban environmental gradients in different cities of Pakistan. International Journal of Biometeorology 59: 267-283. 
25.Khan AN, Khan SN (2015). Drought Risk and Reduction Approaches in Pakistan. In: Rahman AU., Khan A., Shaw R. (eds) Disaster Risk Reduction Approaches in Pakistan. Disaster Risk Reduction (Methods, Approaches and Practices). Springer, Tokyo

26.Khan SI, Hong Y, Gourley JJ, Khattak MU, Groeve TD (2014). MultiSensor Imaging and Space-Ground Cross-Validation for 2010 Flood along Indus River, Pakistan. Remote Sens, 6: 2393-2407.

27.Kundzewicz ZW, Kanae S, Seneviratne SI, Handmer J, Nicholls N, Peduzzi P, Mechler R, Bouwer LM, Arnell N, Mach K, Muir-Wood R, Brakenridge GR, Kron W, Benito G, Honda Y, Takahashi K, Sherstyukov B (2013). Flood risk and climate change: global and regional perspectives. Hydrological Sciences Journal, 59(1): 1-28.

28.Khan AH (2004). The influence of La-Nina phenomena on Pakistan's precipitation. Pakistan Journal of Meteorology, 1: 23-31.

29.Kim WM, Yeh SW, Kim JH, Kug JS, Kwon MH (2011). Theunique2009-2010 El Niño event: A fast phase transition of warm pool El Niño to La Niña. Geophysical Research Letters, 38: L15809.

30.Lee T, McPhaden MJ (2010). Increasing intensity of El Niño in the central-equatorial Pacific, Geophysical Research Letters, 37: L14603.

31.Mahmood A, Masood AKT, Faisal N (2006). Relationship between El Nino and summer monsoon rainfall over Pakistan. Pakistan Journal of Marine Sciences, 15(2): 161-178.

32. Mahmood A, Masood AKT, Faisal N (2004). Correlation between multivariate ENSO index (MEI) and Pakistan's summer rainfall. Pakistan Journal of Meteorology, 1(2): 53.

33.Mustafa D, Wrathall D (2011). Indus Basin Floods of 2010: Souring of a Faustian Bargain? Were the 2010 Pakistan floods predictable? Water Alternatives, 4: 72-85. 
34.National Disaster Management Authority (2011). NDMA annual report. Islamabad, Pakistan.

35.Punjab Development Statistics (2014). Bureau of Statistics Punjab Report. Pakistan.

36.Pal I, Singh S, Walia A (2013). Flood Management in Assam, INDIA: A review of Brahmaputra Floods. International Journal of Scientific and Research Publications, 3(10).

37.Rashid A (2004). Impact of El-Nino on summer monsoon rainfall of Pakistan. Pakistan Journal of Meteorology, 35: 35-43.

38.Syvitski JPM, Brakenridge GR (2013). Causation and Avoidance of Catastrophic Flooding along the Indus River, Pakistan. GSA Today, 23:4-10.

39.Tripathi P (2015). Flood Disaster in India: An Analysis of trend and Preparedness. Interdisciplinary Journal of Contemporary Research, 2(4).

40.Torti J (2012). Floods in Southeast Asia: A health priority. Journal of Global Health, 2(2): 020304.

41.UN Escape (2015). Disasters in Asia and the Pacific: 2015 year in review. United Nations report. Economic and social commission for Asia and the Pacific.

42.Webster PJ, Toma VE, Kim HM (2011). Were the 2010 Pakistan floods predictable? Geophysical Research Letters, 38: L04806.

43.WWF (2001). Dams accused of role in flooding: Research Paper: "Dams and Floods". World Wide Fund For Nature.

44.Yu L, Zhong S, Heilman WE, Bian X (2017). A comparison of the effects of El Niño and El Niño Modoki on subdaily extreme precipitation occurrences across the contiguous United States, J. Geophys. Res. Atmos., 122, doi:10.1002/2017JD026683. 


\begin{tabular}{|l|l|l|lr|}
\hline Sr. & Authors & $\begin{array}{l}\text { Year of } \\
\text { Publication }\end{array}$ & $\begin{array}{l}\text { Regions of study for riveri5ळ5 } \\
\text { flooding }\end{array}$ & 506 \\
\hline 1 & Arnell \& Gosling & 2016 & Asia & 507 \\
\hline 2 & Dewan & 2015 & Bangladesh \& Nepal & 508 \\
\hline 3 & Kundzewicz et al. & 2013 & Global & 509 \\
\hline 4 & Doocy et al. & 2013 & Asia & 510 \\
\hline 5 & Torti & 2012 & South Asia & 511 \\
\hline 6 & WWF & 2001 & Southeast Asia & 512 \\
\hline 7 & UN Escape & 2015 & Asia & 513 \\
\hline 8 & Tripathi & 2015 & India & 514 \\
\hline 9 & Pal et al. & 2013 & India & 515 \\
\hline 10 & Ghosh and Mistri & 2015 & India & 516 \\
\hline 11 & Chohan et al. & 2015 & Pakistan & 517 \\
\hline
\end{tabular}

Tables

Table 1. Studies on riverine flooding in different parts of Asian continent

Table 2: Change Detection Statistics for May 2009, August 2009 and July 2010

\begin{tabular}{|l|l|l|l|l|l|}
\hline & Built Up & Water & Soil & Vegetation & Class Total \\
\hline Water & 0 & 69.897 & 5.003 & 5.398 & 100 \\
\hline Vegetation & 0 & 12.12 & 11.242 & 60.976 & 100 \\
\hline Soil & 0 & 9.248 & 78.718 & 29.487 & 100 \\
\hline Built Up & 0 & 5.294 & 4.657 & 3.584 & 100 \\
\hline Class Total & 0 & 100 & 100 & 100 & 0 \\
\hline Class Changes & 0 & 30.103 & 21.282 & 39.024 & 0 \\
\hline Image Difference & 0 & 188.269 & 25.865 & -31.281 & 0 \\
\hline
\end{tabular}




\begin{tabular}{ccccccc}
\hline Class Names & May 2009 & August 2009 & July 2010 & August 2010 & September 2010 & December 2010 \\
\hline Vegetation & 2326.65 & 3634.54 & 3581.53 & 4789.99 & 4906.46 & 2611.84 \\
Soil & 2320.20 & 1038.04 & 1018.48 & 1338.35 & 1532.89 & 2221.83 \\
Water & 172.60 & 211.12 & 349.40 & 873.48 & 467.61 & 126.70 \\
Built Up & 4064.37 & 3991.5 & 3934.41 & 1162.71 & 1322.66 & 3923.45 \\
Cloud & 0.00 & 0 & 0.00 & 719.29 & 654.17 & 0.00 \\
Total & 8809.23 & 8809.54 & 8809.43 & 8809.35 & 8809.8 & 8809.46 \\
\hline
\end{tabular}

546

547

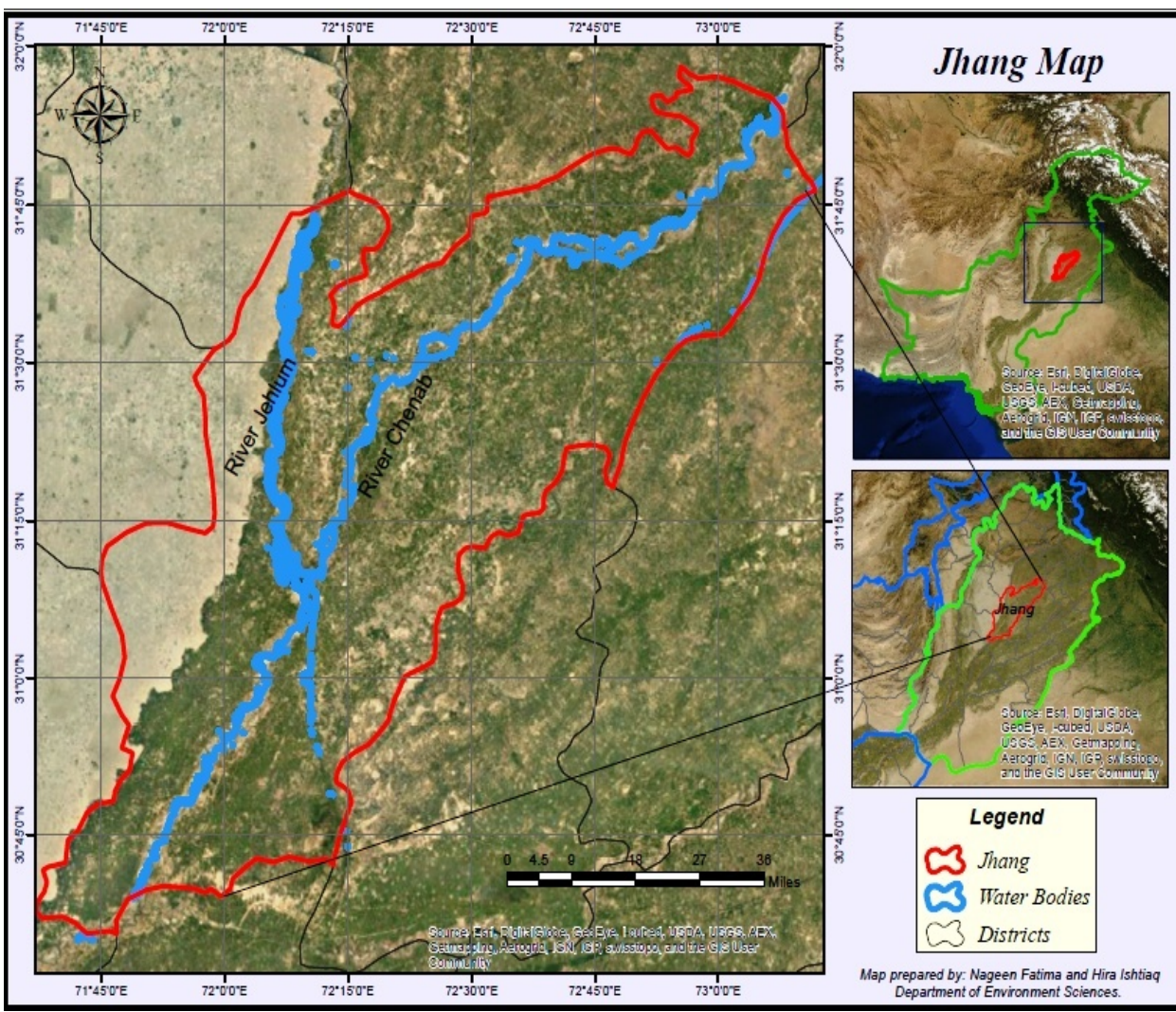

Fig 1. Map of study area showing the meeting point of Jhelum and Chenab Rivers on the 551 boundary map of Jhang district; it is also showing the location of the Jhang district on the boundary map of Pakistan and on the boundary map of the Punjab province 
Fig 2. Flow direction in the Jhang district has been shown, the water flow is mainly towards south and south east

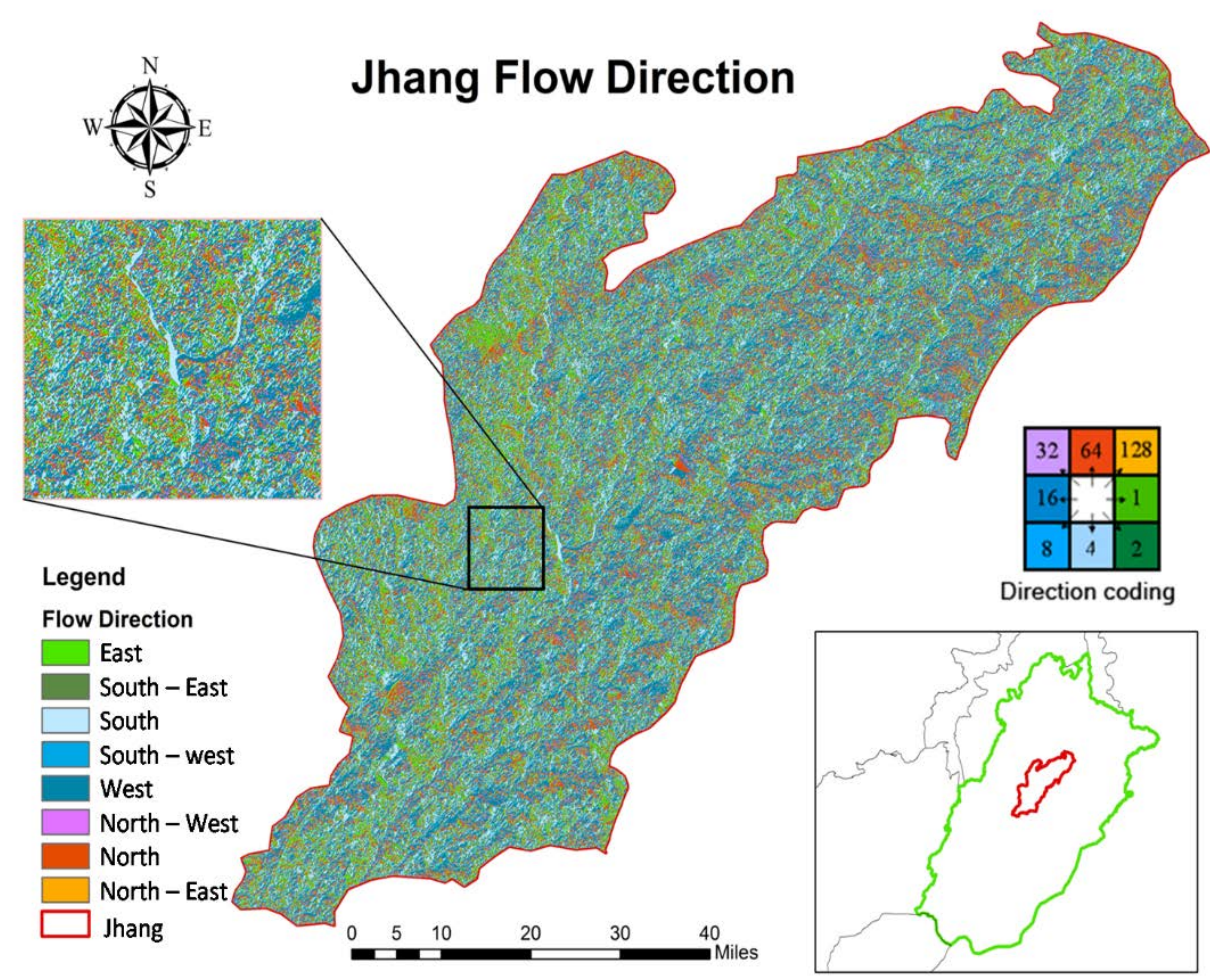

Fig 3. High flow accumulation conditions represented by stream features and drainage density in different colors is shown in the Jhang district

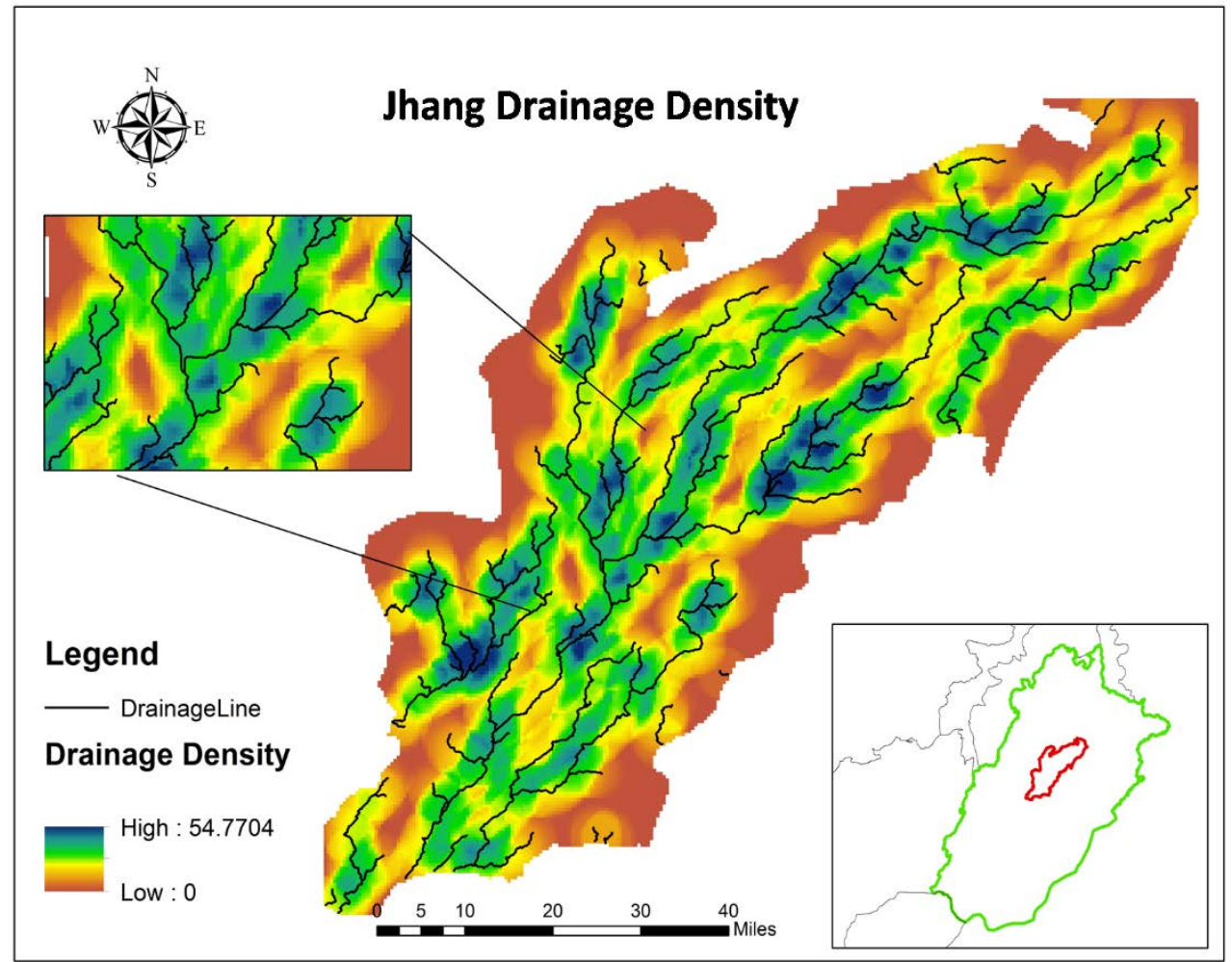


Fig 4. Identification of catchments in the Jhang district

\section{1- Pre- Flooding instance}

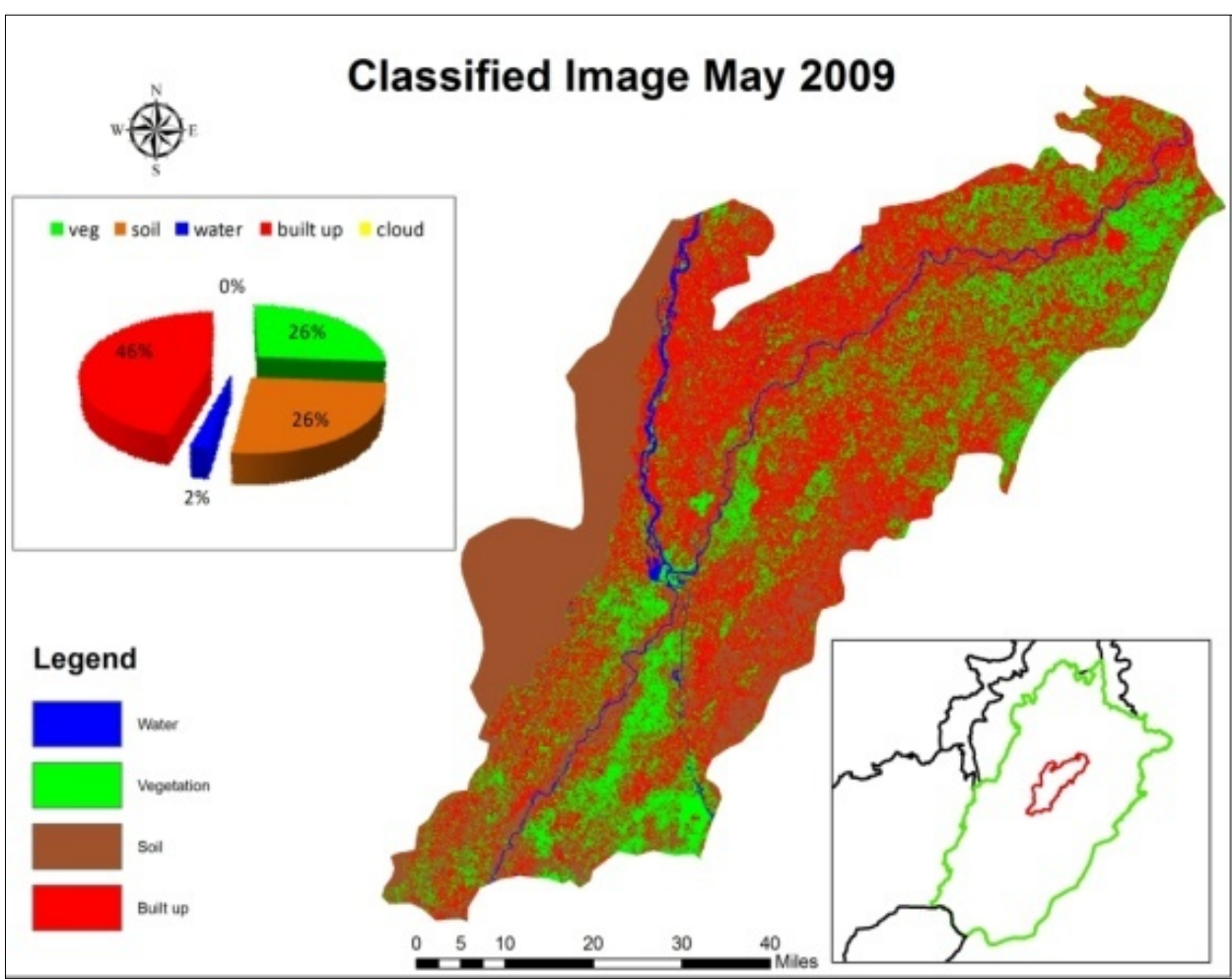

Fig 5. Classification of the Jhang district for May 2009 as pre flooding instance 


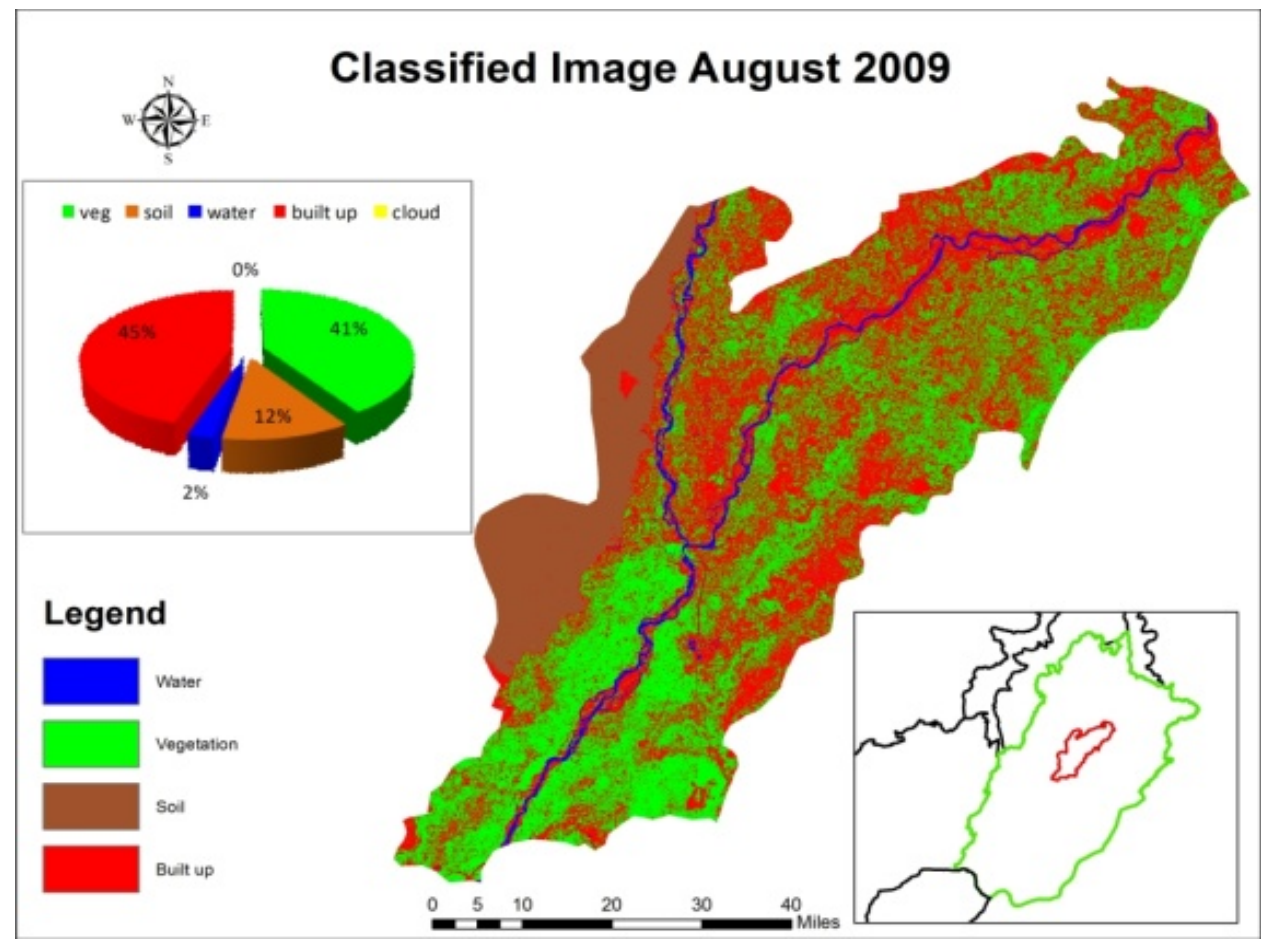

Fig 6. Classification of the Jhang district for August 2009 as pre flooding instance

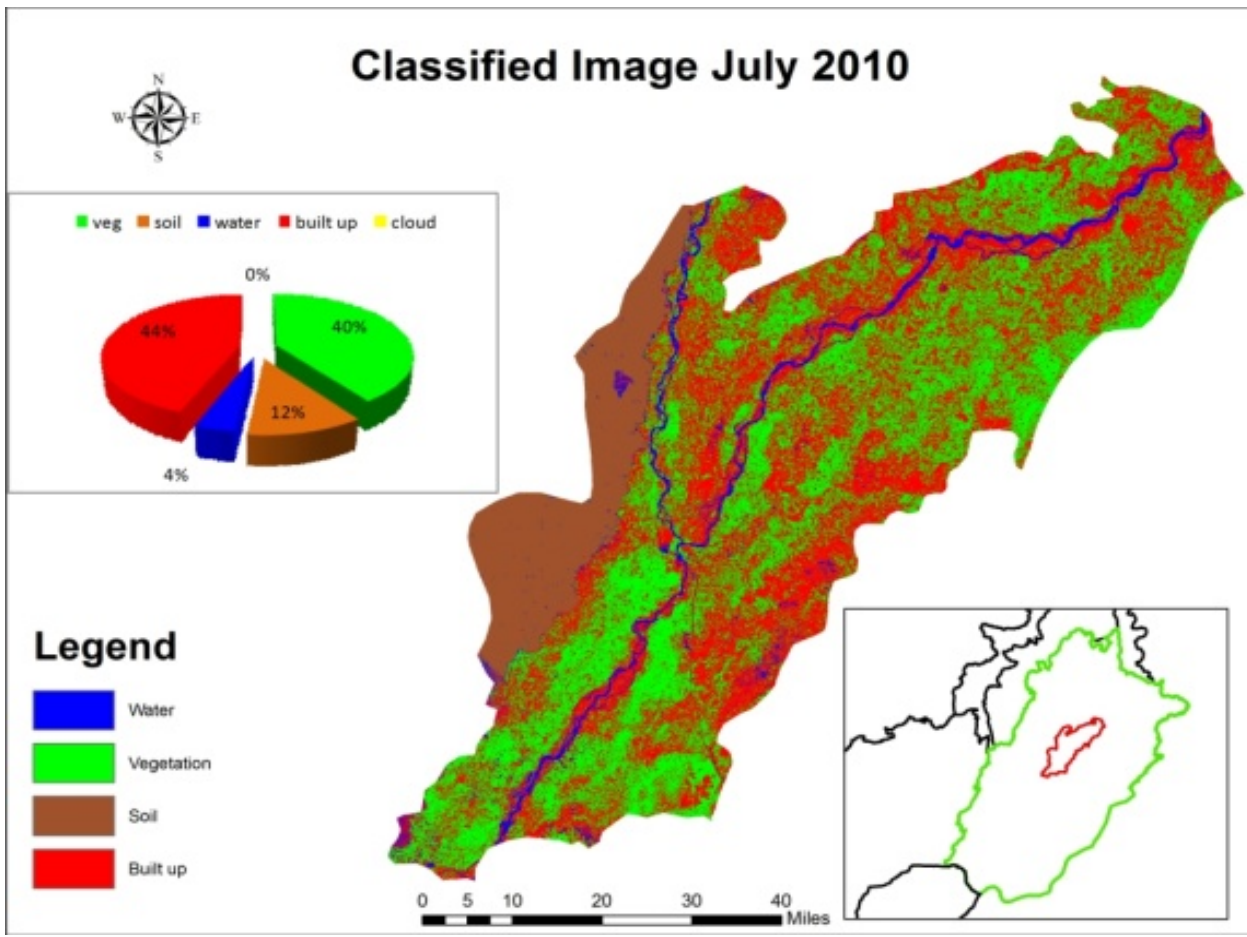

Fig 7. Classification of the Jhang district for July 2010 as pre flooding instance 


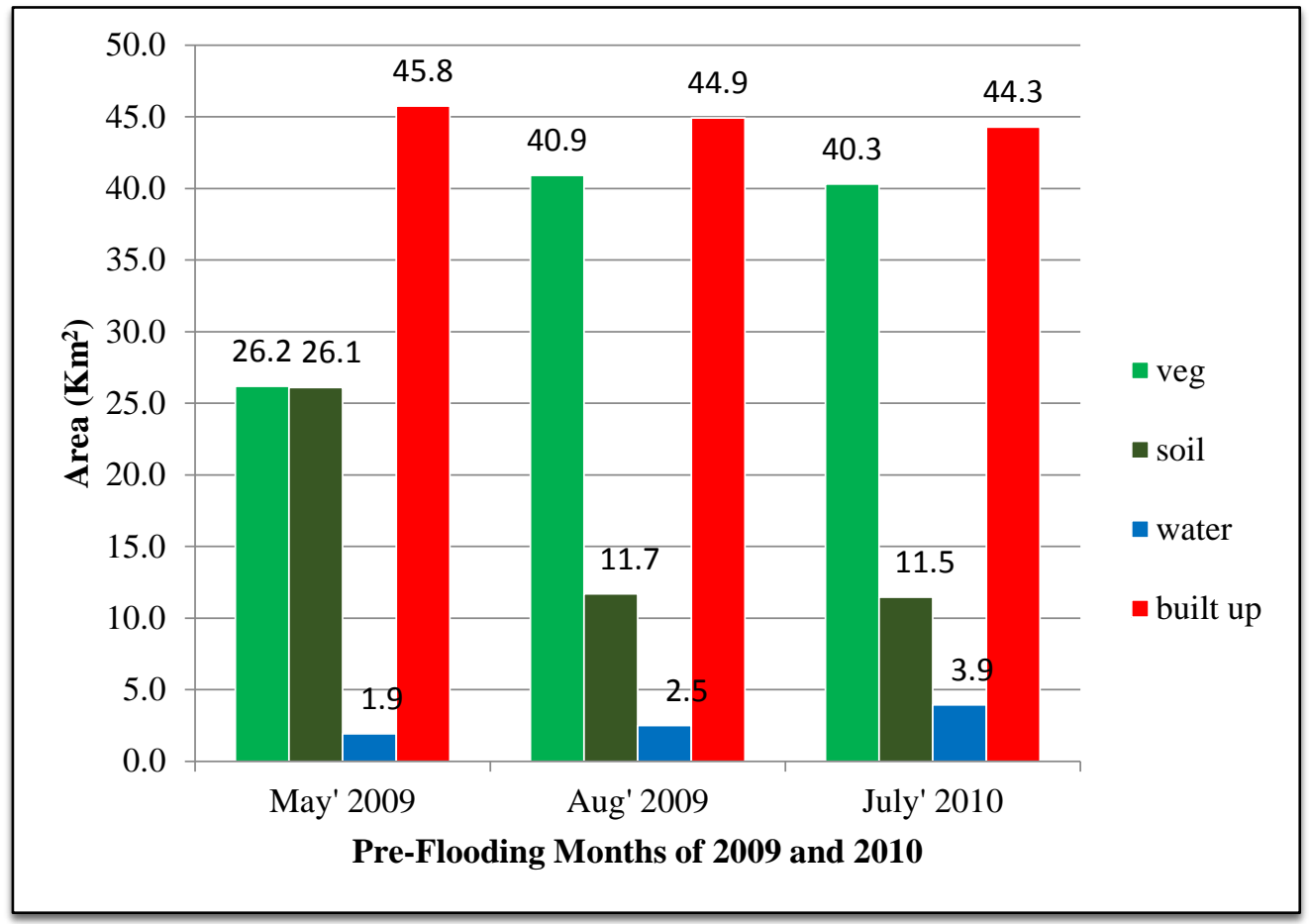

Fig 8. Comparison of results in pre flooding instance classification in the Jhang district for 2009-2010 


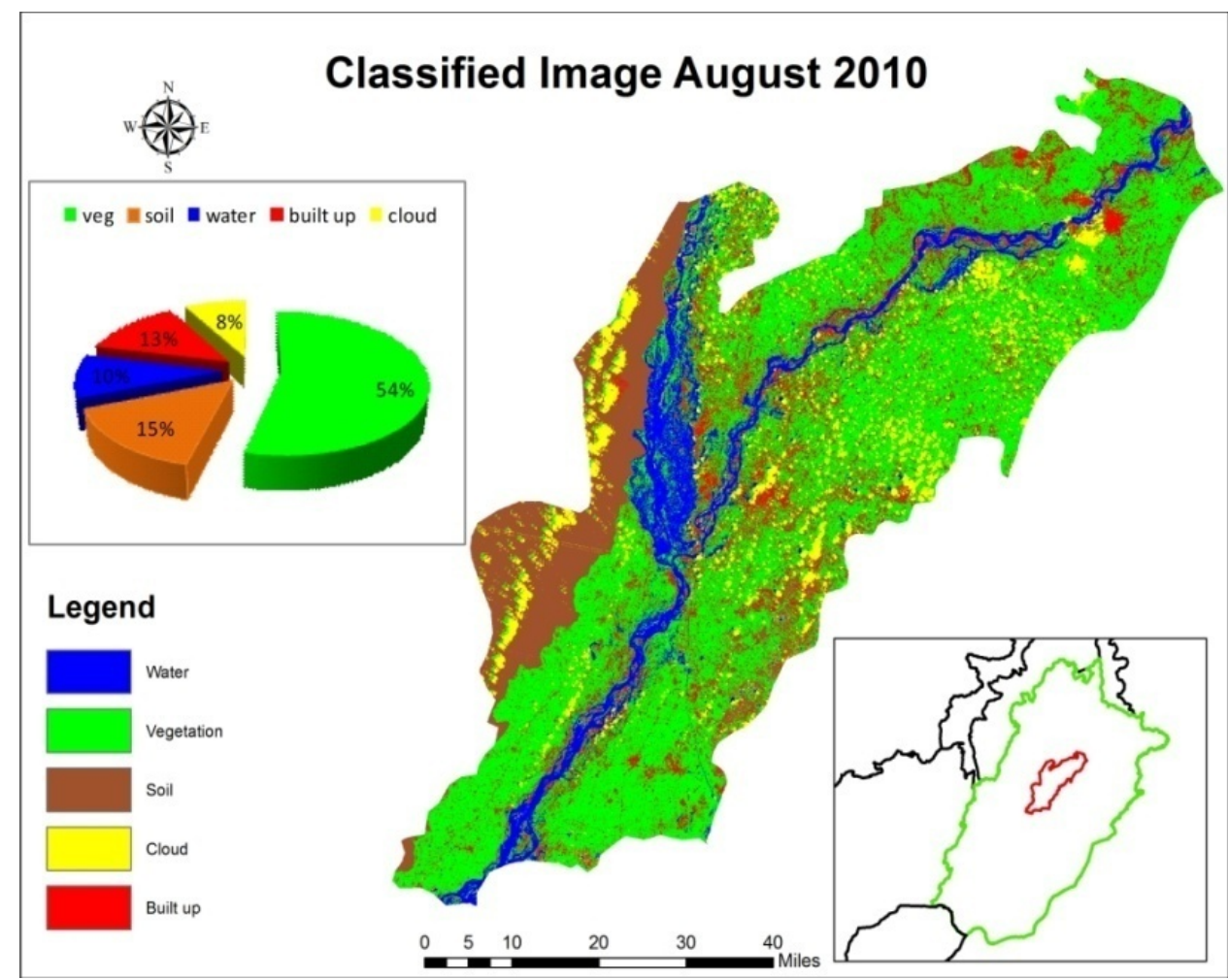

Fig 9 Classification of the Jhang district for August 2010 as a flooding instance

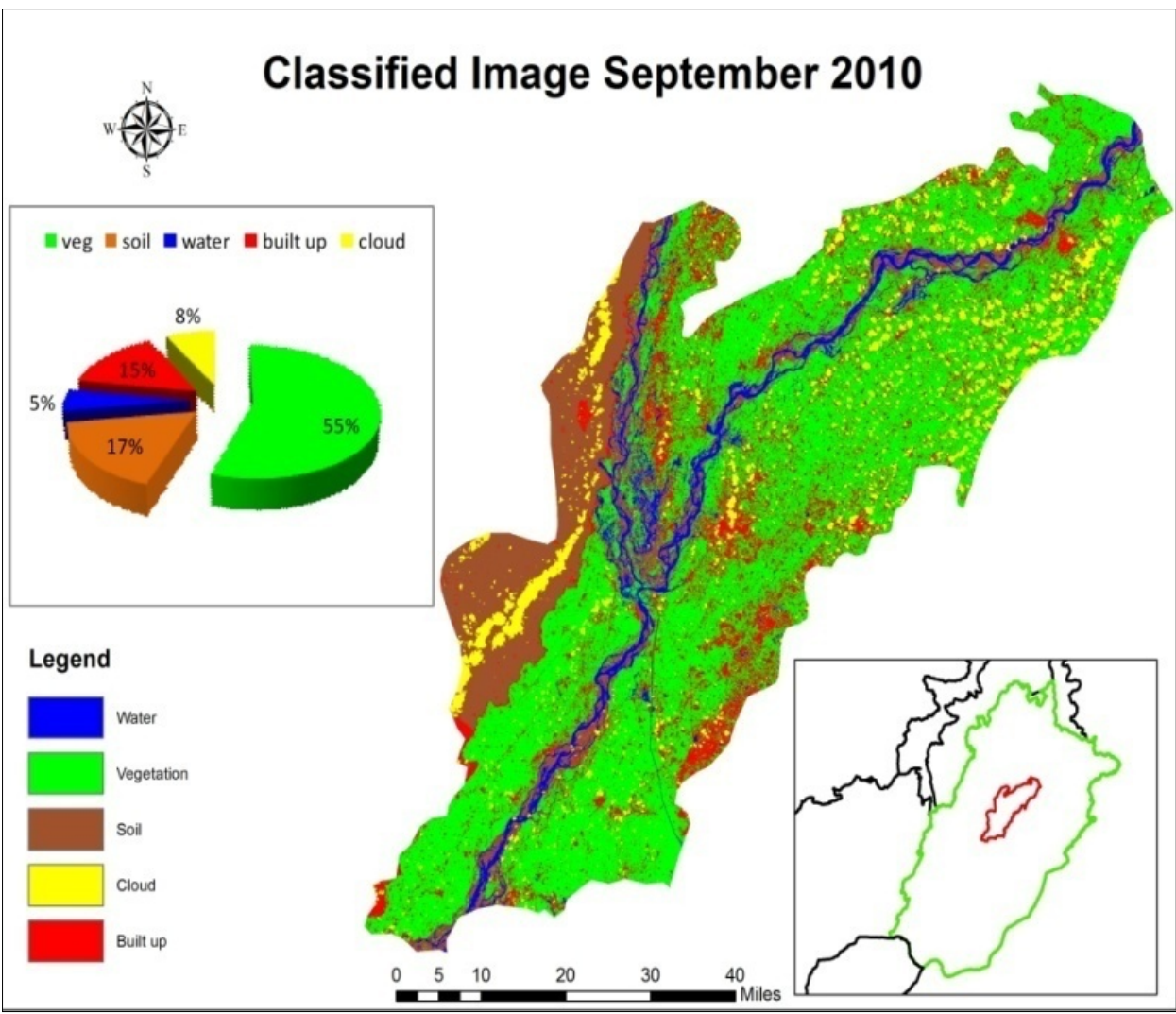

Fig 10 Classification of the Jhang district for September 2010 as a flooding instance 


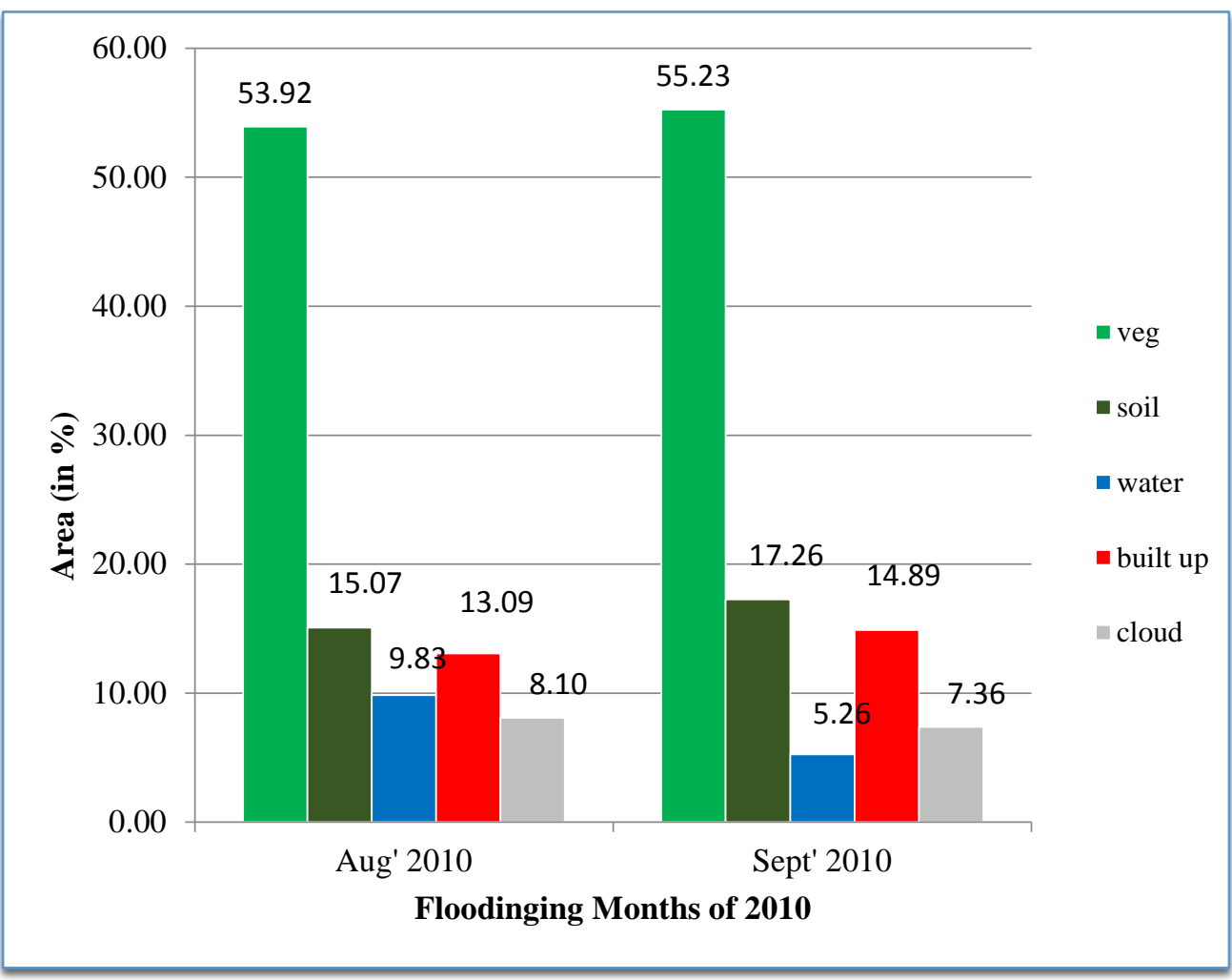

Fig 11. Comparison of identified classes in flooding classification instance in the Jhang district for year 2010

\section{3- Post Flooding instance}

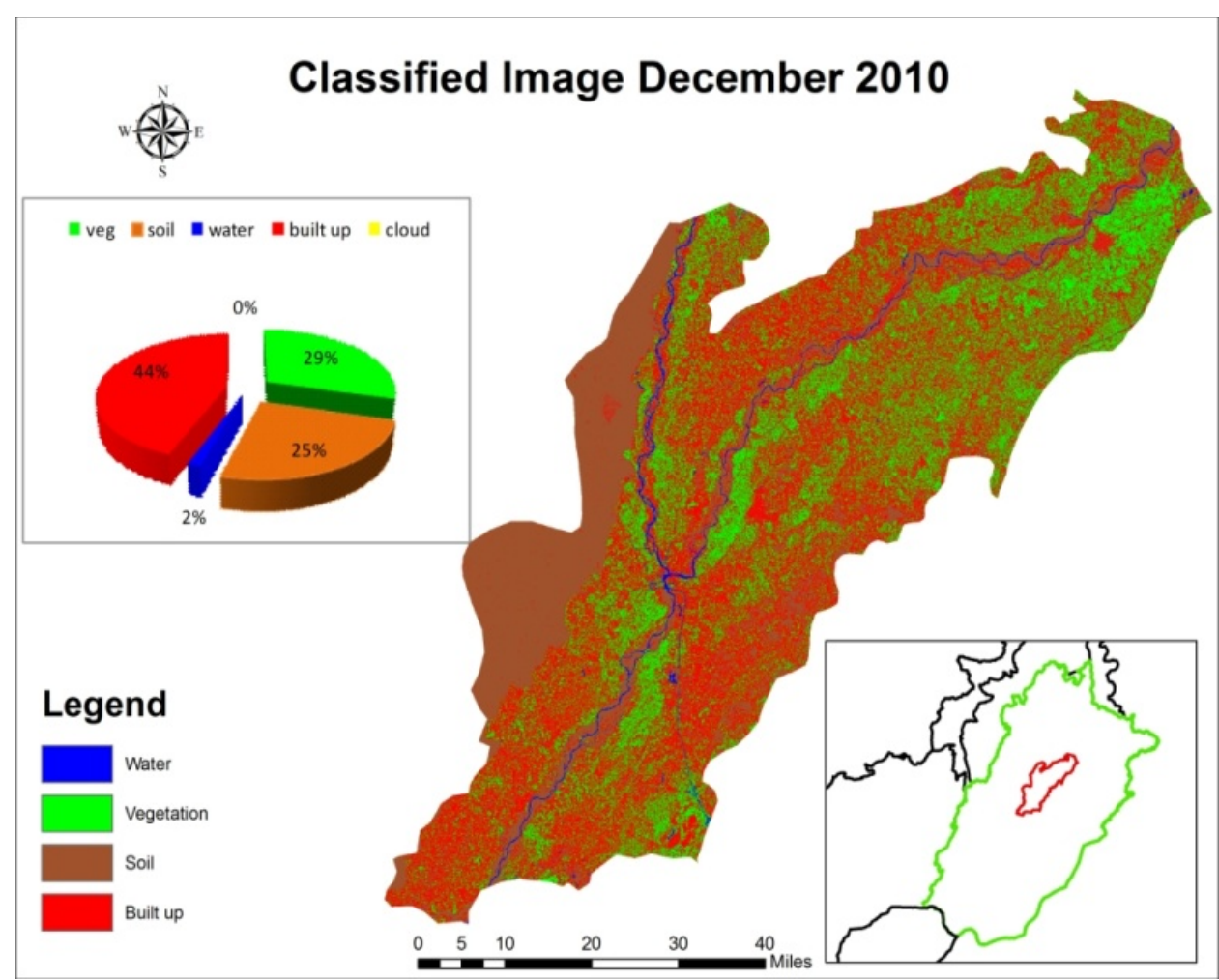

Fig 12 Classification of the Jhang district for December 2010 as a post-flooding instance 


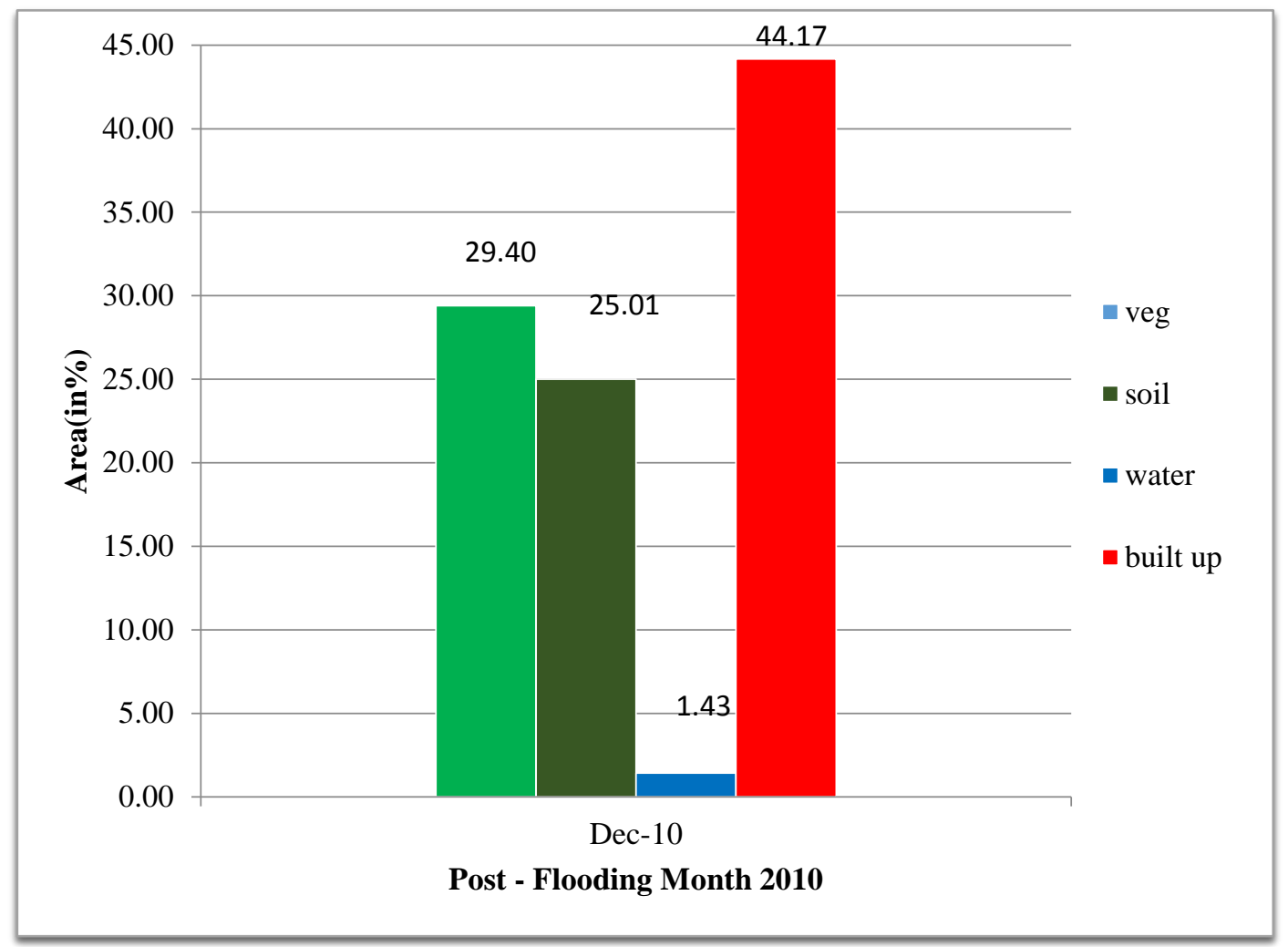

Fig 13. Comparison of identified classes in post-flooding classification instance in the Jhang district for year 2010

ERA INTERIM Climatology Precipitation - 1979-2008

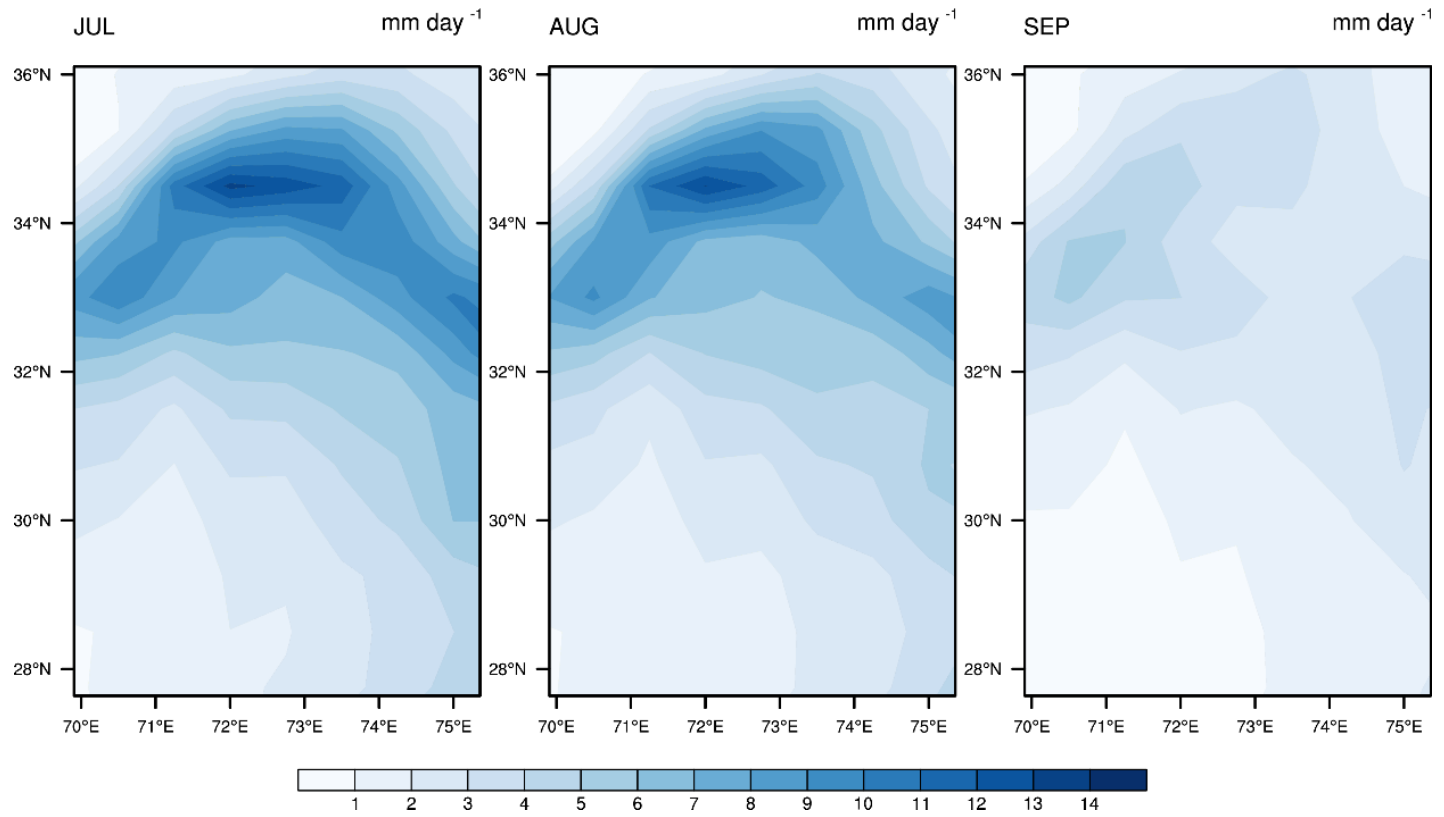

Fig 14. Climatology (1979-2008) showing rainfall patterns for JAS over UIB 
ERA INTERIM Precipitation - 2009

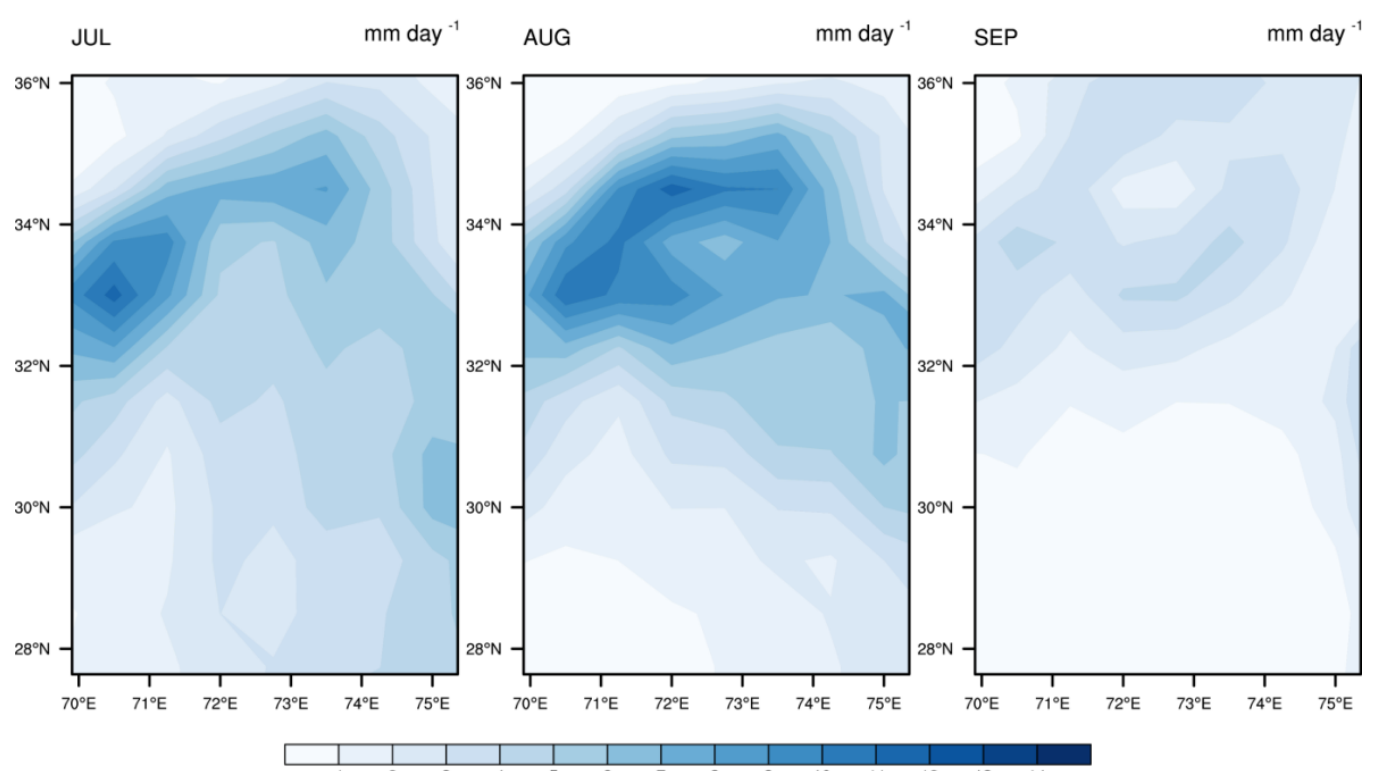

618

619

620

621

622

623

Fig 15. Rainfall pattern prevailed during 2009 over UIB in JAS

ERA INTERIM Precipitation - 2010

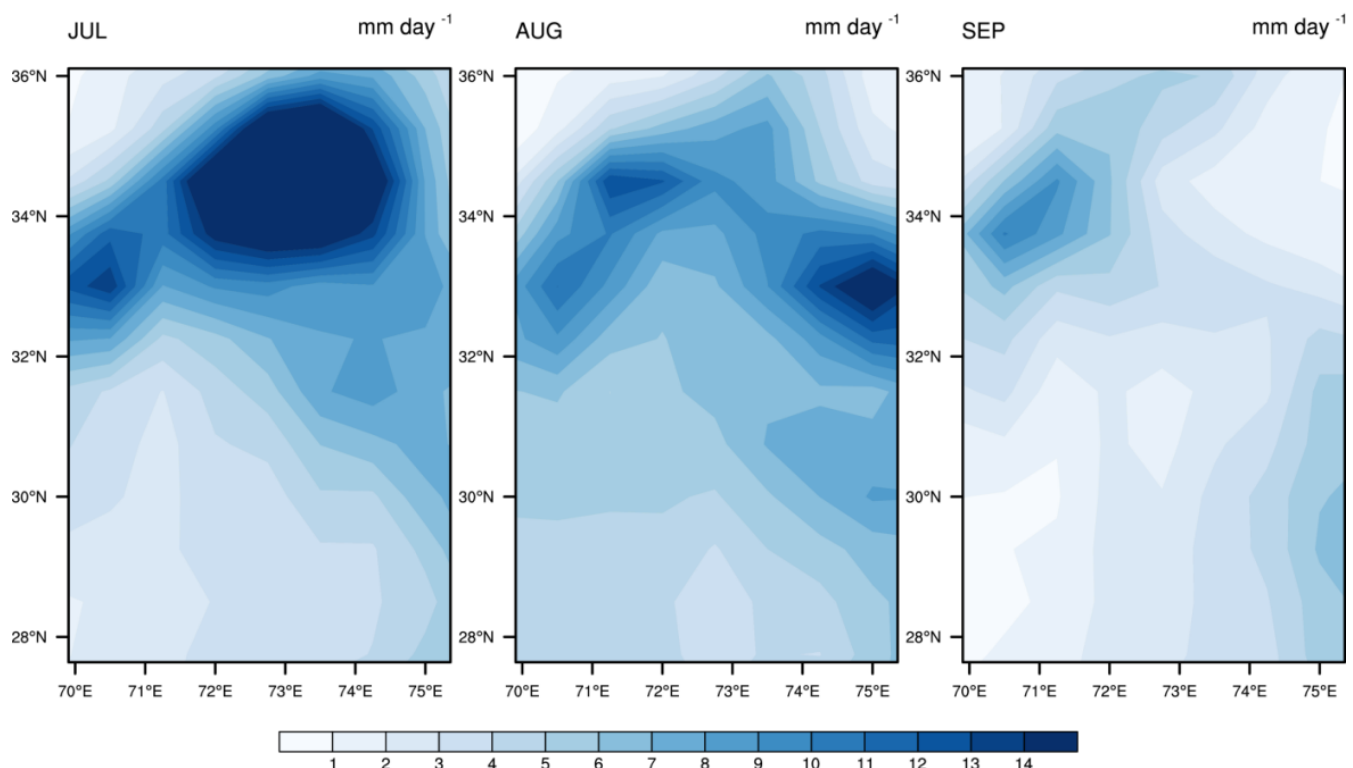

Fig 16. Rainfall pattern prevailed during 2010 over UIB in JAS 
ERA INTERIM Precipitation - 2011

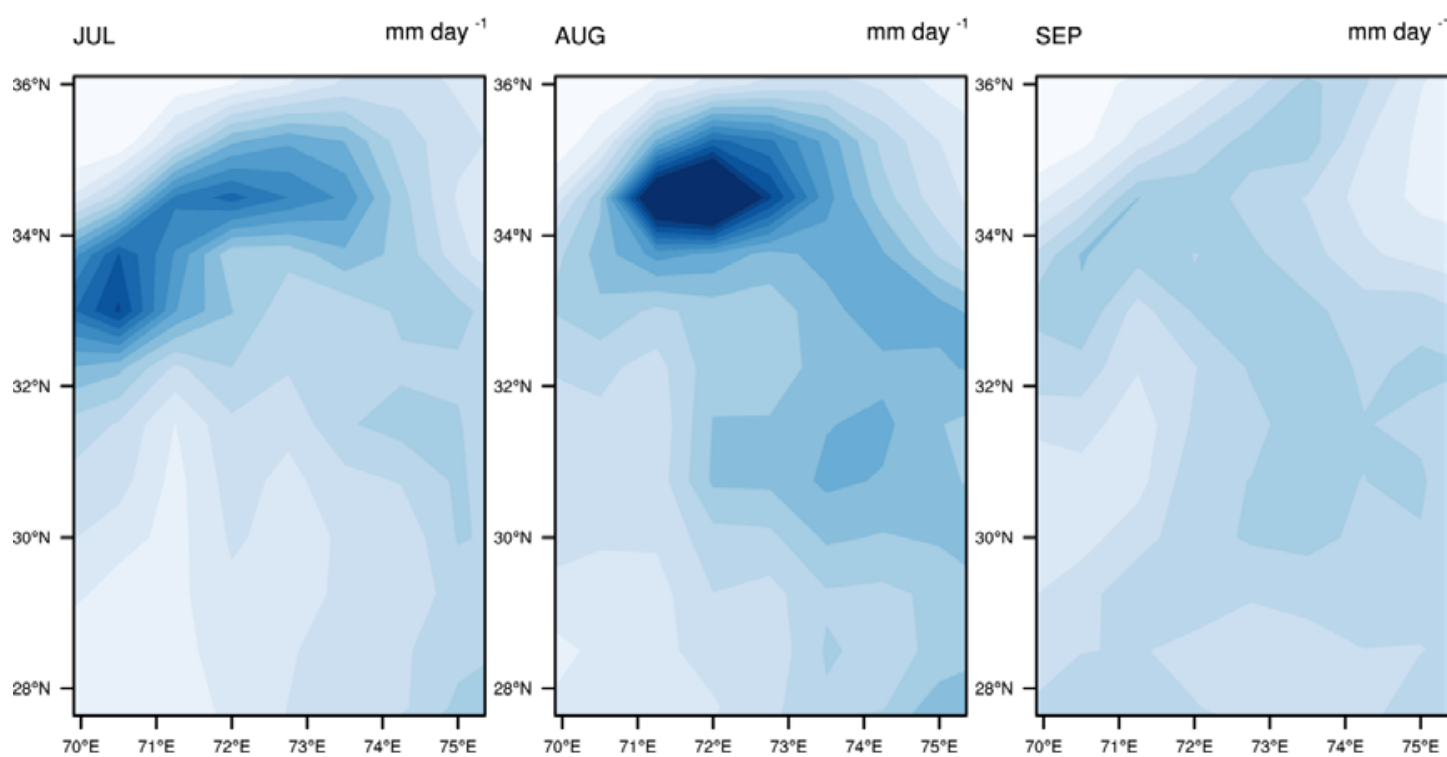

Fig 17. Rainfall pattern prevailed during 2011 over UIB in JAS ERA INTERIM Anomaly Precipitation - 2009

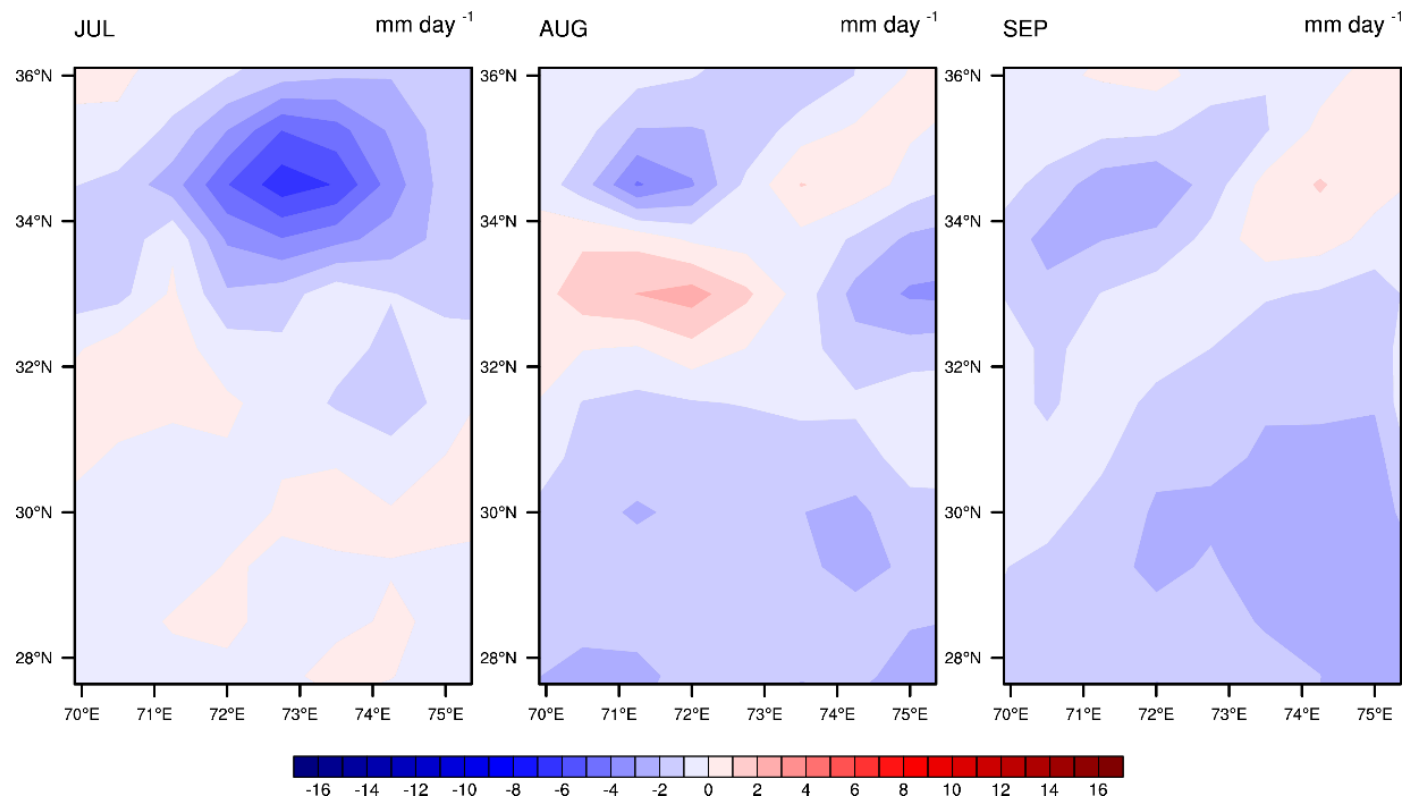

Fig 18. Rainfall anomaly over UIB in JAS during 2009 
ERA INTERIM Anomaly Precipitation - 2010

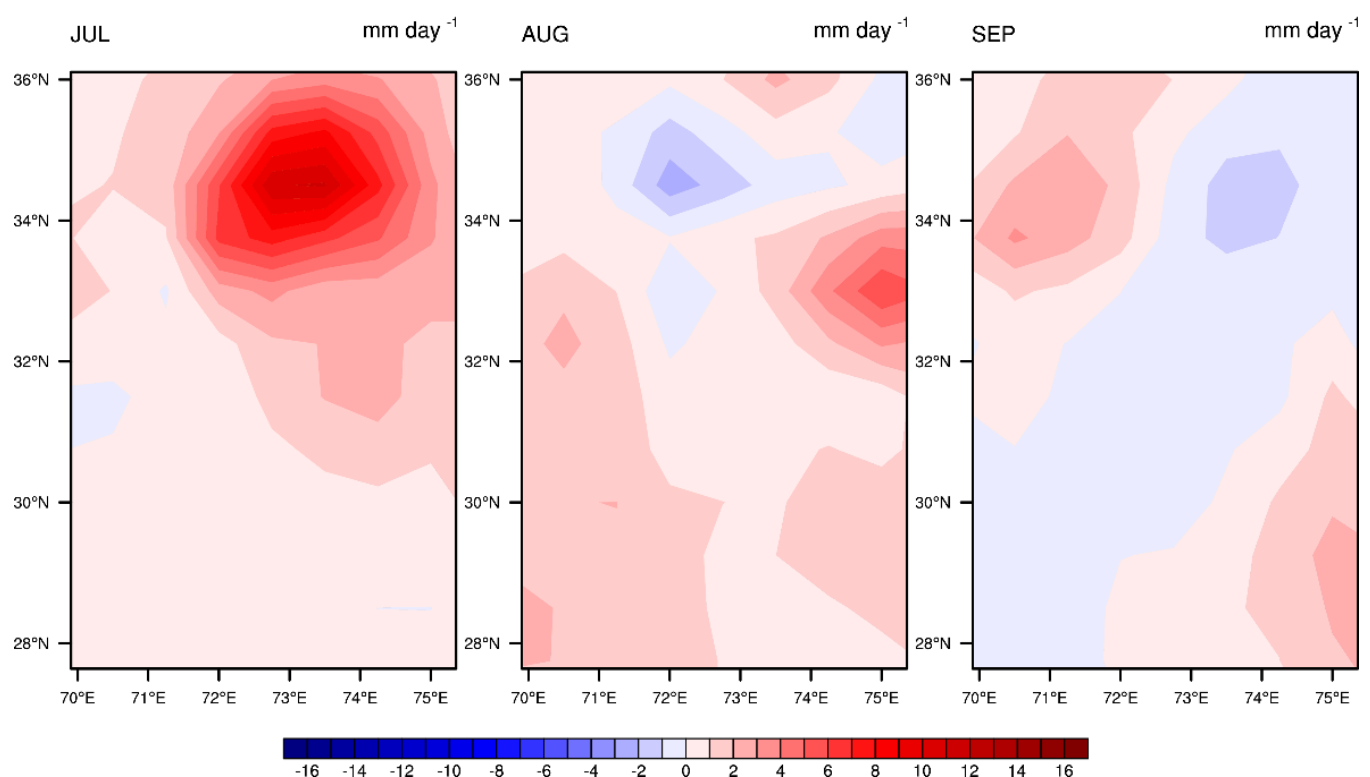

Fig 19. Rainfall anomaly over UIB in JAS during 2010

ERA INTERIM Anomaly Precipitation - 2011

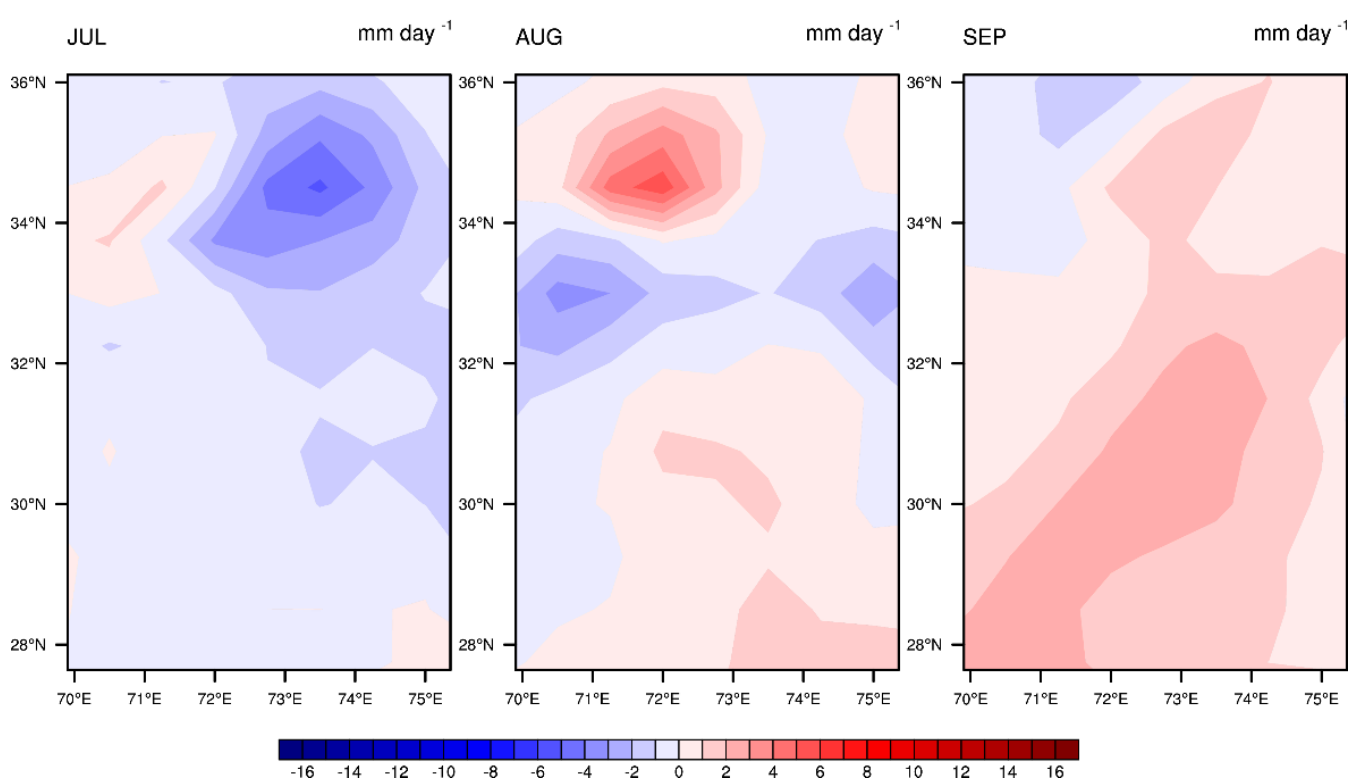

Fig 20. Rainfall anomaly over UIB in JAS during 2011 
Standard deviation Climatology - 1979-2008

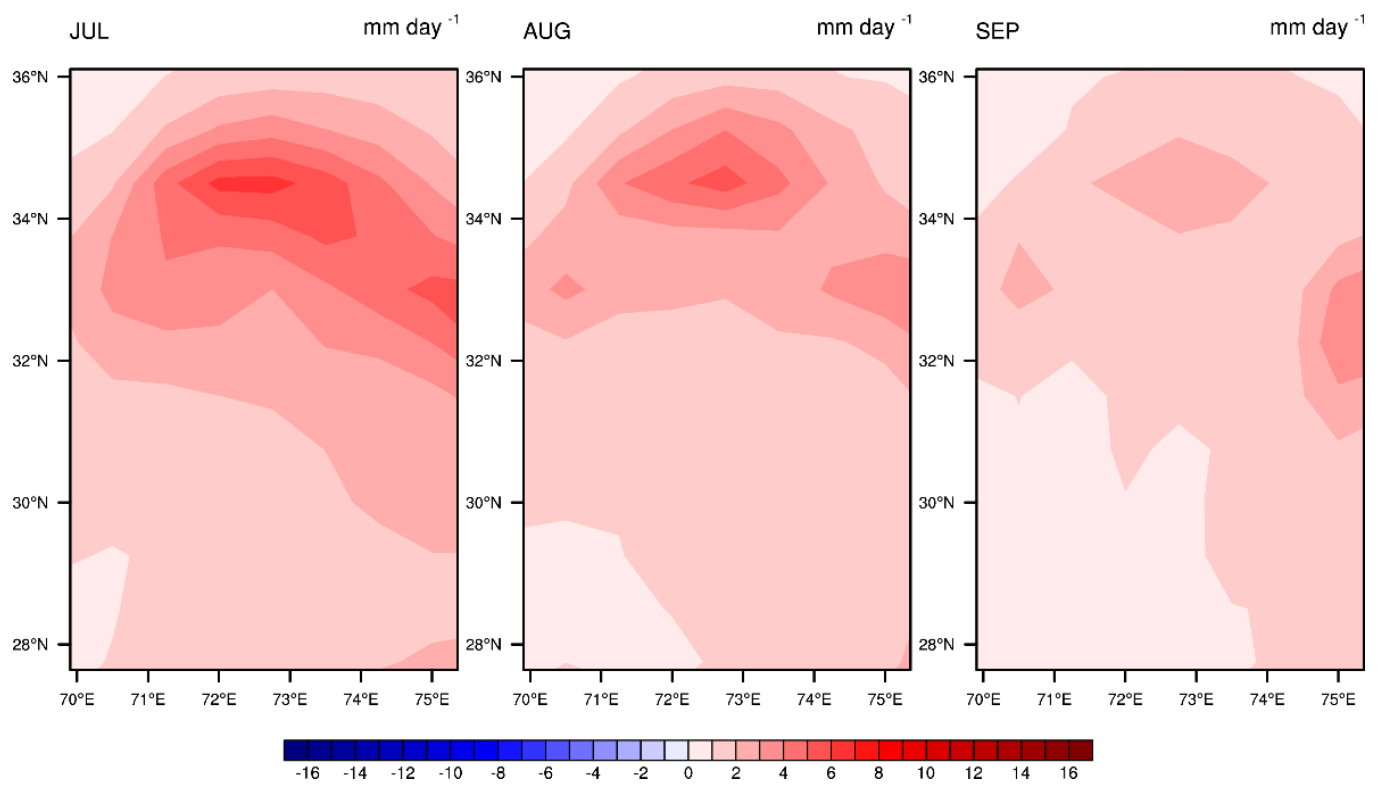

Fig 21. Standard deviation of climatology (1979-2008) over UIB during JAS

\section{Standard deviation Climatology - 2009-2011}

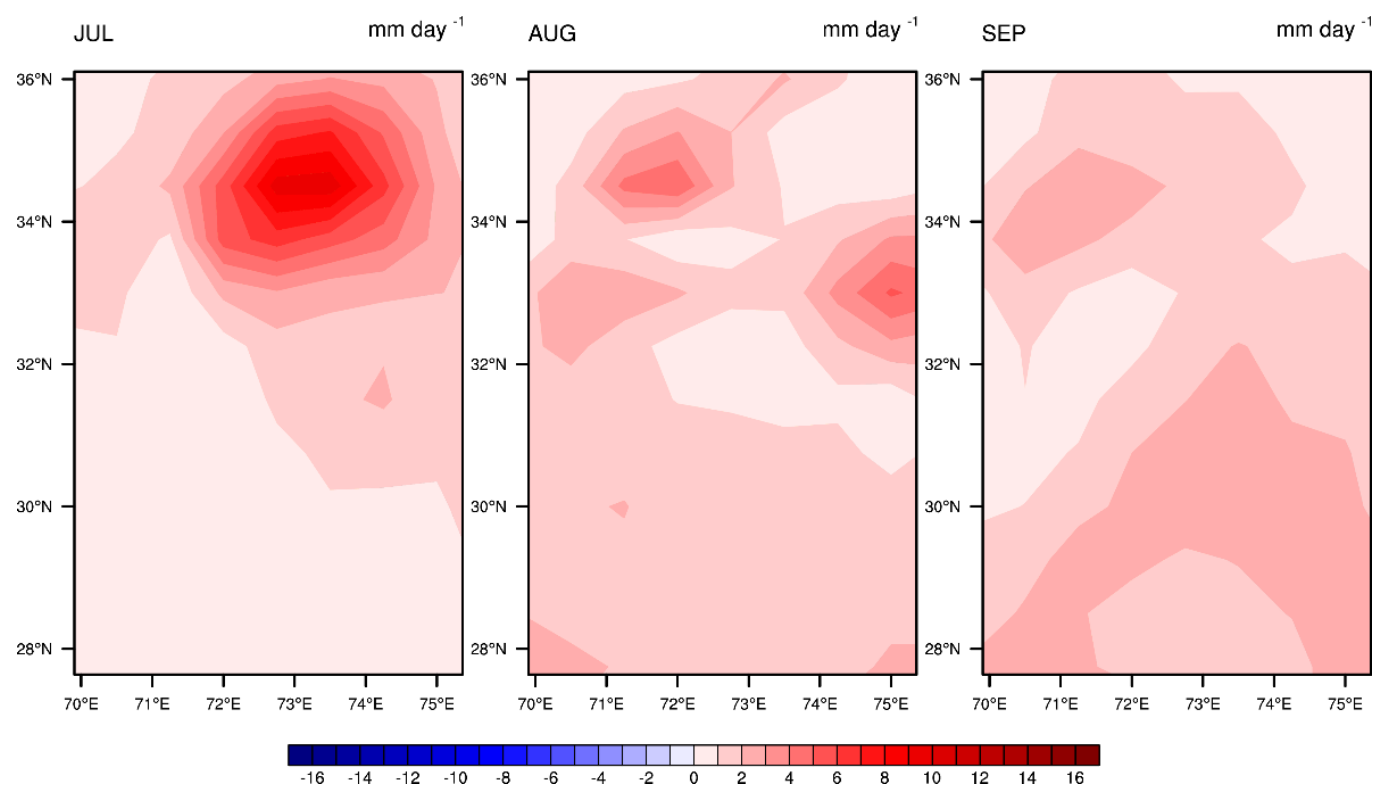

Fig 22. Standard deviation of climatology (2009-2011) over UIB during JAS 
Daily rainfall trend from 1979-2016 over upper Indus basin region

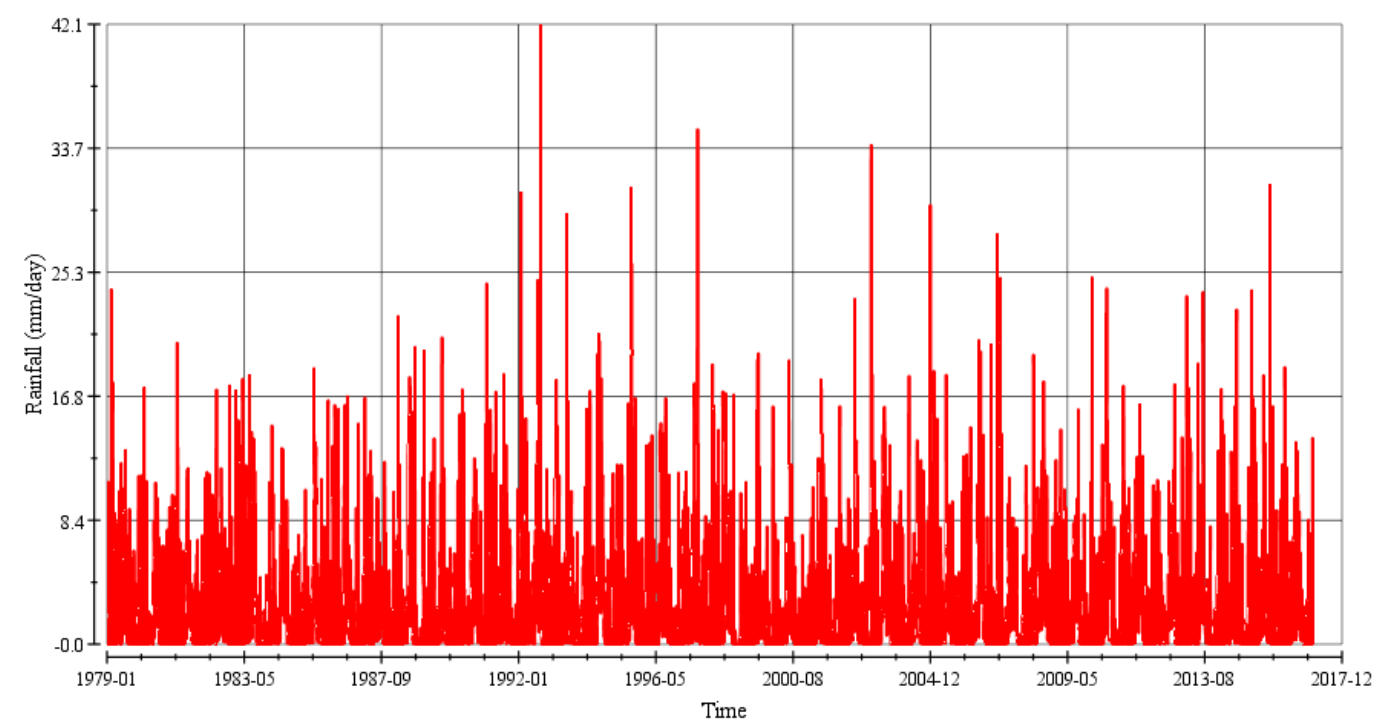

- Daily rainfall trend 1979-2016

656

657

658

Figure 23. Rainfall trend in Upper Indus Basin region for 1979-2016

El Nino events from 1981 to 2017 showing peak in 2009

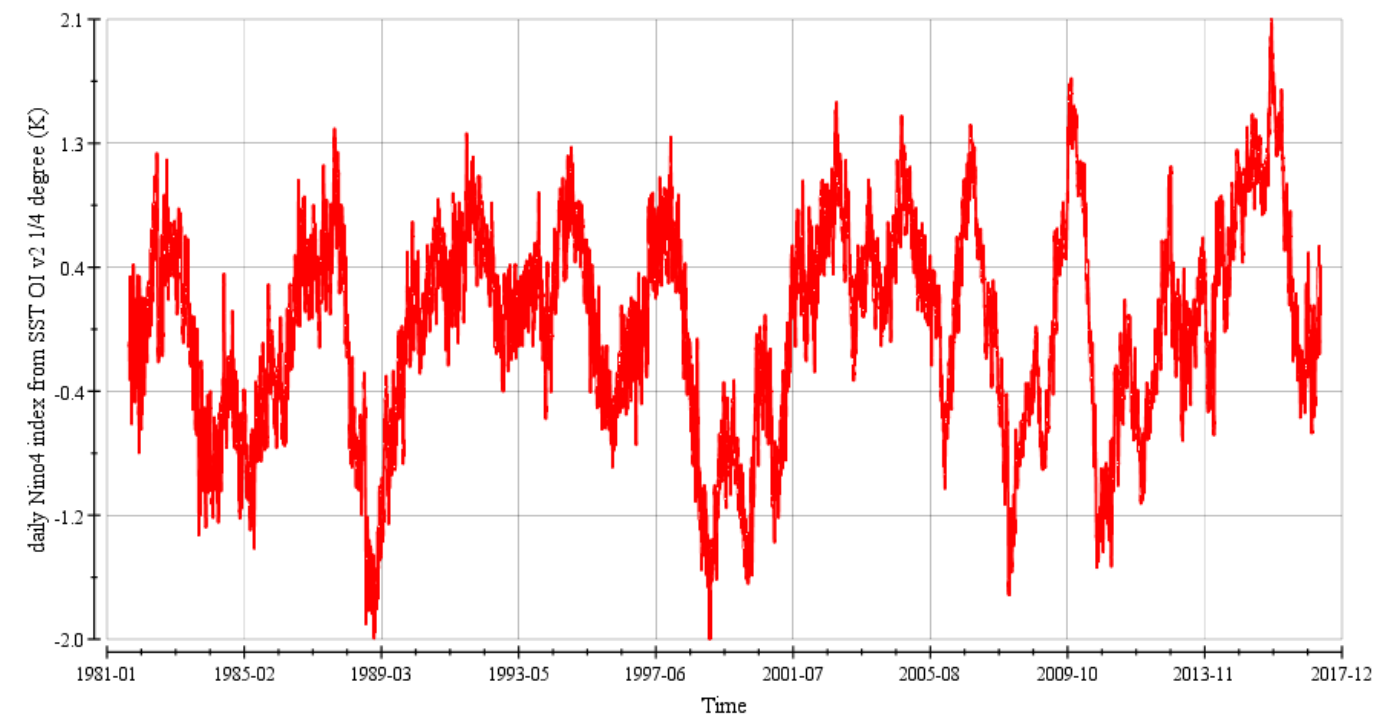

— daily Nino 4 index from SST OI v2 1/4 degree (K)

659

660

661

662

663
Fig 24. The peaks represents occurrence of El Nino while the lower values represents occurrence of La Nina events during 1981-2017 